\title{
Evolution of negative visual frames of immigrants and refugees in the main media of Southern Europe
}

\author{
Javier J. Amores; Carlos Arcila-Calderón; David Blanco-Herrero
}

Nota: Este artículo se puede leer en español en:

https://profesionaldelainformacion.com/contenidos/2020/nov/amores-arcila-blanco_es.pdf

How to cite this article:

Amores, Javier J.; Arcila-Calderón, Carlos; Blanco-Herrero, David (2020). "Evolution of negative visual frames of immigrants and refugees in the main media of Southern Europe". Profesional de la información, v. 29, n. 6, e290624.

https://doi.org/10.3145/epi.2020.nov.24

Manuscript submitted on May 26, 2020 Accepted on August 24, 2020

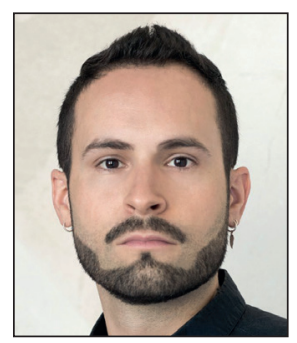

Javier J. Amores $\square$

https://orcid.org/0000-0001-7856-5392

Universidad de Salamanca

Facultad de Ciencias Sociales

Campus Miguel de Unamuno, Edificio FES

Av. Francisco Tomás y Valiente, s/n.

37007 Salamanca, Spain

javieramores@usal.es

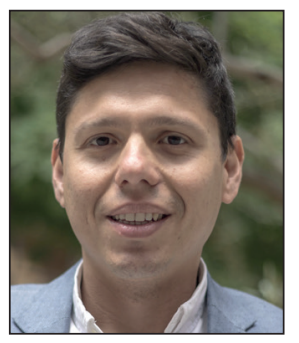

Carlos Arcila-Calderón

https://orcid.org/0000-0002-2636-2849

Universidad de Salamanca

Facultad de Ciencias Sociales

Campus Miguel de Unamuno, Edificio FES

Av. Francisco Tomás y Valiente, $s / n$.

37007 Salamanca, Spain

carcila@usal.es

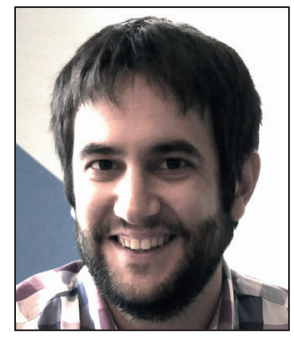

\author{
David Blanco-Herrero \\ https://orcid.org/0000-0002-7414-2998 \\ Universidad de Salamanca \\ Facultad de Ciencias Sociales \\ Campus Miguel de Unamuno, Edificio FES. \\ Av. Francisco Tomás y Valiente, $\mathrm{s} / \mathrm{n}$. \\ 37007 Salamanca, Spain \\ david.blanco.herrero@usal.es
}

\begin{abstract}
The Mediterranean migration crisis especially affects three Southern European countries that represent the main gateways into the continent for immigrants and asylum seekers: Greece, Italy, and Spain. In recent years, feelings of rejection towards migration have been increasing in all of them, accompanied by a simultaneous increase in the number of hate crimes. Similarly, the representation of these groups in European news media seems to have worsened, especially since 2015 , the year in which the migratory crisis significantly worsened. This coverage could be affecting European citizens on emotional, cognitive, and attitudinal levels and thus should be rigorously analyzed. The present study is based on the theory of framing and, specifically, on visual framing to analyze the connotative representations of immigrants and refugees spread by the reference media of Southern Europe through images, paying more attention to the negative frames in particular, which represent displaced people as a burden or threat. Specifically, 360 photographs taken between 2014 and 2019 and published by the main media in Greece, Italy, and Spain were subject to content analysis. The findings show a temporal increase in the negative visual frames of immigrants and refugees in the analyzed media. Differences were also found between countries, with Greece presenting a higher percentage of images with negative frames, as well as a greater predominance of this type of frame compared with the other countries. Finally, differences were identified between the media themselves, being the Greek Kathimerini the one that stands out for having a greater presence and prevalence of visual frames that represent inmigrants and refugees as a burden and threat.
\end{abstract}

Funding

This work has been made possible thanks to the financial support of Castilla y León Regional Government's Ministry of Education and the European Social Fund through a Grant for hiring research personnel in training (EDU/556/2019); as well as the European Commission that, through the Rights, equality, and citizenship program (REC-RRAC-RACl-AG-2019), finances the Preventing hate against refugees and migrants (Pharm) project. 


\section{Keywords}

Framing theory; Visual frames; Photographs; News media; Immigrants; Refugees; Migration crisis; Refugee crisis; Prejudice; Rejection; Southern Europe.

\section{Introduction}

The massive entry of immigrants and asylum seekers into Europe since 2015 has awakened remarkable scientific interest in researching the answers that citizens, media, and public institutions are giving to foreigners, posing new challenges regarding their adaptation to social dynamics resulting from human mobility. Undoubtedly, the social response is determined by a set of social, economic, and cultural factors, but, to a great extent, it has been mediated by public discourses of acceptance and rejection reproduced in the media. Far from a "solidary" perception, the spread of negative frames in which these immigrants are considered a burden on or threat to the country or local culture should be noted, which helps to consolidate attitudes of rejection, as well as an increase in the amount of hate speech and crimes against this vulnerable population.

Moreover, this situation is worse in Southern European countries (Greece, Italy, and Spain), which have been the entrance for forced migration, especially during the so-called Mediterranean crisis, caused mostly by the massive movement of Syrian, Iraqi, and Afghan people, although thousands of people of other nationalities have also used this route to flee similar conflicts. In this regard, Greece, Italy, and Spain represent a rather cohesive group, sharing similar cultural features, but facing a common problem, as shown by the great media attention focused on immigration in recent years.

There is broad agreement in the scientific literature surrounding the way in which frames shared by the media play a determinant role in sensitive topics such as migration (Muñiz; Igartua; Otero, 2006; Van-Gorp, 2005; Zhang, 2005), and there is growing interest in understanding the role of visual framing in news coverage of these topics. Said interest is based on the acknowledgement of the huge impact that photographs can have on public attitudes, as well as the understanding of how a particular selection and organization of certain photographic attributes can influence different degrees of interpretation. In any case, there is an important gap in the research on how the most damaging visual frames and attributes (negative ones in terms of burden or threat) transmitted by the media have evolved over time in countries with similar experiences in the migratory crisis. The present study intends to fill this gap by analyzing the evolution of connotative visual frames about immigrants and refugees in photographs published by the main media in Southern European countries between 2013 and 2019.

In the following sections, this article conceptualizes the attributes that build these negative visual frames about immigrants and refugees: it explains the evolution of the rejection of this group in terms of attitudes, perceptions, and extreme discourses, it details the selection of a sample of photographs and subsequent content analysis, the obtained results, and finally, it discusses these results through the perspective of the existing literature in this field and the theory of framing.

\section{Evolution of the rejection of immigrants and refugees in Southern Europe}

We begin this section by contextualizing the different experiences of immigration in the three countries present in this study, especially the Mediterranean refugee crisis beginning in 2015. Traditionally, Italy has been mostly affected by African immigration, particularly during the Arab Spring in 2011, and with some very dramatic shipwrecks -in October 2013, a shipwreck near Lampedusa caused the death of 366 people and led to the launch of the Mare Nostrum Operation - before the media began to focus on the migration crisis in 2015. After 2015, Italy experienced a large increase in the number of arrivals using the central Mediterranean route, prompting a significant change in the country's migration discourse (Stocchiero, 2017). This migratory crisis had a particularly intense impact in Greece, with the largest volume of refugees, mostly Syrians coming from Turkey, entering the country, and subsequently taking the Balkan route towards other European countries. Greece not only overflowed due to the volume of arrivals, but also due to its weak economic situation, causing a more complex challenge (Kaitatzi-Whitlock; Kenterelidou, 2017) that reached crisis point and consequently warranted European-level measures in the form of the 2016 EU-Turkish deal to combat the problem and return migrants. Lastly, the beginning of the immigration phenomenon in Spain goes back to the beginning of the new century, between the 1990s and 2000s, with events such as the Cayuco Crisis in the Canary Islands in 2006, or various attempt to jump the fences of Ceuta and Melilla. The Syrian refugee crisis was seen more distantly (Seoane-Pérez, 2017), although it gained relevance as the volume of refugees taking the Greek and Italian routes dwindled after the EU-Turkish agreement and the closure of harbors.

The arrival of immigrants and asylum seekers to Europe has also been associated with an increase in anti-immigration and nationalist discourse and the influence of certain political parties (Dennison; Geddes, 2019; Burscher; Van-Spanje; De-Vreese, 2015). Both trends have led to a growth in media coverage of the topic of migration (Georgiou; Zaborowski, 2017; Colombo, 2018), which, in turn, could have influenced the support that these political parties receive (Damstra et al., 2019). In this context, although negative media coverage of immigration can produce negative attitudes towards immigrants (Eberl et al., 2018; Schemer, 2012), there is still no general consensus on the extent to which news frames, both textual or visual, can influence the attitudes that European citizens hold toward immigration, nor on the effect that these attitudes can have on the potential influence of media content. For this reason, it is important to continue to 
explore the evolution of this discourse in the media, along with the framing of this discourse and the relationship with attitudes and perceptions towards immigrants and refugees.

According to the Standard Eurobarometer from November 2019 (European Commission, 2019b), European citizens resident in the three focal countries of this paper consider immigration to be the most concerning and relevant challenge faced by the European Union. Although this Standard Eurobarometer offers data about the Common European Asylum System (more favored by Spanish and Greek citizens than Italian) and the strengthening of EU borders (more favored in Greece than in Italy and Spain), the Special Eurobarometers offer more information of interest for this study, especially those related to immigration. The Special Eurobarometer 493: Discrimination in the European Union (European Commission, 2019a), from May 2019, shows that ethnic origin, skin color, or religion are perceived as causes for discrimination among European countries, although to a lesser extent than in the previous version from May/June 2015 (European Commission, 2015). That survey, taken before the refugee crisis in the Mediterranean, became a media phenomenon in most European countries, offered particularly negative views, with more perceived discrimination than in 2012.

A more detailed survey with data from October 2017, the Special Eurobarometer 469: Integration of Immigrants in the European Union (European Commission, 2018), contains the most up-to-date information about attitudes towards migrants and the potential influence of frames used in the media on these attitudes. The survey suggested that Italian, Greek, and Spanish citizens feel poorly informed about immigration, while tending to overestimate both the volume and proportion of illegal immigrants living in their countries. Moreover, Greek citizens have the most contact with immigrants, on average, along with Italians and Spanish citizens as well. This is understandable given that these three countries make up the main entrances to the EU -although, according to Eurostat official figures, their proportion of immigrant population is close to the average amount for European countries, highlighting their status as entry rather than destination countries. Regarding their attitudes at a national level, Spanish citizens generally claim to feel comfortable interacting with immigrants; Spain is second on the list of countries with residents claiming to have immigrants as friends or family members, while these values in Greece are well below average, and those in Italy are close to average. This trend is similar in most variables, with Spain being among the countries with the most positive attitudes towards immigration, perceiving integration to be successful and not considering immigration to be such a problem, whereas Italy and Greece show values close to or even below the average in these matters.

In the majority of studies analyzing Western perceptions of immigrants and refugees, a connection is made between negative attitudes and the perception of these groups as a burden on or threat to the host societies. This is the case for a study conducted by the Pew Research Center in 2016, researched and written during the migratory crisis in Europe and the Mediterranean entitled "Europeans fear wave of refugees will mean more terrorism, fewer jobs." According to this study, European sentiment towards refugees is predominantly negative in most Western countries, mostly due to the perception of these minorities as a threat. As seen in Table 1, results from this investigation show that, within Southern Europe, Spain is the country where a smaller percentage of citizens consider refugees a burden or threat. Meanwhile, Italy is the country in which a greater percentage of citizens consider refugees a threat, and Greece is the country in which a greater percentage consider them a burden. Negative attitudes toward refugees are linked to economic aspects of a country, as well as to their rate of terrorism or crime, as European citizens see newcomers as a threat, both to economic prosperity and to peace, respect, and social welfare.

Table 1. Negative perceptions about refugees in Southern Europe in 2015

\begin{tabular}{|l|c|c|c|}
\hline Country/question & $\begin{array}{c}\text { Refugees are a burden on our } \\
\text { country because they take our jobs } \\
\text { and social benefits }\end{array}$ & $\begin{array}{c}\text { Refugees in our country } \\
\text { are more to blame for } \\
\text { crime than other groups }\end{array}$ & $\begin{array}{c}\text { Refugees will increase } \\
\text { the likelihood of terrorism } \\
\text { in our country }\end{array}$ \\
\hline Spain & $40 \%$ & $13 \%$ & $40 \%$ \\
\hline Italy & $65 \%$ & $47 \%$ & $60 \%$ \\
\hline Greece & $72 \%$ & $30 \%$ & $55 \%$ \\
\hline
\end{tabular}

Source: Spring 2016 Global attitudes survey, Q51a-c. In: Wike, Richard; Stokes, Bruce; Simmons, Katie (2016). "Europeans fear wave of refugees will mean more terrorism, fewer jobs." Pew Research Center, 11.

The Pew Research Center is also responsible for the Spring 2018 Global Attitudes Survey, in which the surveyed are asked whether they perceive immigration as a strength or burden, concluding that most citizens from the 18 main destination countries for immigrants believe that these people make their countries stronger. This was the case in Spain, but not in Italy or Greece, two of the countries that demonstrated the most negative opinions in this category. Similarly, there was a minority in Spain that reported perceiving immigrants as a threat, as more responsible for crimes than other groups, or as stimulating terrorism in the country, while in Italy, and especially Greece, negative responses increased significantly (Table 2). These results show an increase in negative perceptions that identify immigrants as a burden for European countries, especially in Greece. To sum up, these data suggest that negative attitudes towards displaced people can be influenced by sociodemographic, political, and media context, given that the migratory pressure is higher in these countries than in other parts of Europe. 
Table 2. Negative perceptions about refugees in Southern Europe in 2017

\begin{tabular}{|l|c|c|c|}
\hline Country/question & $\begin{array}{c}\text { Refugees are a burden on our } \\
\text { country because they take our } \\
\text { jobs and social benefits }\end{array}$ & $\begin{array}{c}\text { Refugees in our country are more } \\
\text { to blame for crime than other } \\
\text { groups }\end{array}$ & $\begin{array}{c}\text { Refugees will increase the likeli- } \\
\text { hood of terrorism in our country }\end{array}$ \\
\hline Spain & $37 \%$ & $29 \%$ & $41 \%$ \\
\hline Italy & $54 \%$ & $44 \%$ & $60 \%$ \\
\hline Greece & $74 \%$ & $59 \%$ & $65 \%$ \\
\hline
\end{tabular}

Source: Spring 2018 Global Attitudes Survey. Around the world. More say immigrants are a strength than a burden.

These results allow us to contextualize the relationships that these countries have with immigration; however, partly due to social and digital media, attitudes of rejection are prevalent in these nations. Bearing this in mind, numerous studies have complemented their traditional survey research (O'Rourke; Sinnott, 2006; Verkuyten; Mephan; Kros, 2018) with analyses of the rejection or feelings shown towards immigration in social media (Gallego; Gualda; Rebollo, 2017; Kreis, 2017).

In general, the study of attitudes (Esses et al., 2005), prejudices, and rejection towards immigrants (Peherson; Brown; Zagefka, 2011) is frequent in the area of Social Sciences, particularly in the analysis of racism, xenophobia, or prejudices towards the "other," the so-called exogroup. This concept has its origin in studies about social identity theory (Tajfel, 1978; Tajfel; Turner, 1979), explaining how the self-conception of a person comes from their belonging to a specific social group. Therefore, we must highlight the relevance of studies discussing rejection and negative attitudes towards immigrants and refugees, as it is these perceptions that can potentially be a precursor to more extreme forms of discrimination, such as hate speech (Contrada et al., 2001; Arcila-Calderón; Blanco-Herrero; Valdez-Apolo, 2020). In fact, online hate speech has become a topic that has received great attention from academia (Burnap; Williams, 2015; Davidson et al., 2017; Valdez-Apolo; Arcila-Calderón; Amores, 2019). This is largely due to evidence showing that online hate speech can act as a trigger for hate crime (Müller; Schwarz, 2018). In fact, a constant increase in the number of registered hate crimes has been observed over the last few years in each of the three countries studied herein (Table 3). Racism and xenophobia are always the most common cause of these crimes.

Table 3. Hate crimes registered by the police in Spain, Italy, and Greece (2014-2018)

\begin{tabular}{|c|c|c|c|}
\hline Year & Spain & Italy & Greece \\
\hline 2018 & 1,598 & 1,111 & 164 \\
\hline 2017 & 1,419 & 1,048 & 128 \\
\hline 2016 & 1,272 & 736 & 40 \\
\hline 2015 & 1,328 & 555 & 60 \\
\hline 2014 & 1,285 & 596 & 71 \\
\hline
\end{tabular}

Source: OSCE. Hate crime reporting.

https://hatecrime.osce.org

This evidence allows us to appreciate the relevance of analyses focusing on societal attitudes towards immigrants, especially rejection and hate speech. Research within Communication Studies has frequently approached the topic of mass media and its potential to influence society, particularly societies' feelings towards certain groups, such as immigrants (Igartua; Muñiz, 2004; Marcos-Ramos et al., 2014; Cheng et al., 2014) or other ethnic minorities (Entman, 1992) through the use of theories such as agenda-setting or framing. In recent years, these theories have been applied to social and digital media, such as the study by Gil-Ramírez and Gómez-de-Travesedo (2020) of the representation of immigration and the Aquarius case on YouTube, although it is true that traditional mass media (mostly press and television) still dominate this branch of research in Communication (Borah, 2011; Matthes, 2009; Piñeiro-Naval; Mangana, 2019; Saperas; Carrasco-Campos, 2015; Vicente-Mariño; López-Rabadán, 2009). Recently, there have been frequent studies using framing theory to study the representation of immigration in the media, especially in the context of the aforementioned migratory crisis (Greussing; Boomgarden, 2017; Amores; Arcila-Calderón; Stanek, 2019). In the present article, we follow this line of work.

\section{Connotative visual frames}

As noted above, framing is one of the theories most widely used in the Social Sciences to study the representation of immigration in the media. This is because it allows a broad approach, with the ability to focus on topic selection, or even on denotative element selection within the news, as well as on more formal aspects involved in the construction of frames, such as the symbolic representation that they transmit or their ideological intention, and finally on the effects these frames have on the audience. The basis of this theory is focused on the different effects that media coverage can have on public opinion, as the media actively set the reference frames used by the audience to interpret and discuss public events (Tuchman, 2002; Weaver, 2007). Currently, it is considered that no media outlet can escape from this framing process in its informative activity via selecting and prioritizing some elements or attributes over others (Entman, 1993). 
This also suggests that news content cannot be seen as free from ideological influence (Fahmy, 2010; Gamson et al., 1992; Tuchman, 2002) given its intrinsic mediated, rather than immediate, nature.

However, these processes do not only occur on the textual level that has been focused on since its creation; rather, framing is equally used more frequently and accurately for graphic and audiovisual news content. Media professionals are aware that the iconic, symbolic, and expressive weight of photography is more significant than that of any written text (Mandell; Shaw, 1973; Messaris; Abraham, 2001; Ramírez-Alvarado, 2011), particularly nowadays, when societies have become more visual than ever due to content overload and its increasingly ephemeral nature. Given the iconic nature of photography, photographs always seem closer to the truth, so much so that spectators tend to ignore the possibility of there being a biased construction with an underlying symbolic and ideological reality (Bock, 2017; Rodríguez; Dimitrova, 2011). Images are easier to interpret by the public as they does not require previous knowledge of representation rules (Zillmann; Gibson; Sargent, 1999), making them the perfect tool to frame, transmit, reinforce, or construct ideas and perceptions.

In this light, it is surprising that visual analysis is not more common in the Social Sciences. Specifically, Palacios (2015) remarks that, among all the studies based on framing, only $17 \%$ focus on visual aspects. Furthermore, this proportion seems to be even smaller in Spanish research, given that, as Piñeiro-Naval and Mangana (2019) point out, only $6.7 \%$ of framing studies in Spanish-American journals indexed in Scopus conduct visual analyses, while $51 \%$ carry out textual ones. Most efforts to study visual elements using framing theory only focus on the denotative level, without identifying the implicit reality transmitted, maybe due to the complexity of dealing with this connotative reality in a reliable and replicable way. This is directly connected with the model of the study of visual frames presented by Rodríguez and Dimitrova (2011), in which four possible levels of analysis are introduced; denotative, stylistic, connotative, and ideological.

This text focuses primarily on the analysis of implicit representation that is transmitted by photographs of immigrants and refugees, as this representation will be responsible for the emotional and cognitive effects on citizens, and the influence of (or equally, the influence on) the ideological frame at the fourth level. Regarding this connotative level of visual analysis, it should be noted that, in any case, it will be motivated by the selection and emphasis of denotative elements within an image and, in the case of photographs of immigrant and refugees, by the defining features of the depicted subjects, such as demographic aspects of gender, age, skin color, religion, job position, or perceived ethnic origin, to the character within the photograph, including their expressions, acts, and behaviors (Amores; Arcila-Calderón, 2019; Amores; Arcila-Calderón; González-de-Garay, 2020). However, in this analytical process, if the connotative features transmitted in a type of image seem to be clear, and are reported as such, there is a chance to examine the third level directly, which can provide the most information about the potential effects of the image (Amores; Arcila-Calderón; Stanek, 2019). For this reason, the main goal of this study is to focus on the third level of visual framing analysis, to identify the way in which Southern European media connotatively represent immigrants and refugees in their photographs, and how this representation has changed over time.

\section{Representation of immigrants and refugees in Western media}

Given the media's capacity to cover events and transmit deliberate perceptions regarding these events and the main actors involved to the audience, it is relevant to pay attention to these representations, especially when they include vulnerable and historically stigmatized groups, such as immigrants and refugees.

In this regard, it seems that Western media have traditionally represented migrants in a negative and mostly prejudiced way (Igartua et al., 2007; Muñiz et al., 2006; Van-Gorp, 2005; Zhang, 2005), frequently connecting them with violent and terrorist acts, especially when the depicted migrants come from the Middle East or North Africa (Kalkan; Layman; Uslaner, 2009; Corral-García; Fernández-Romero, 2015; Maataoui, 2006; Said, 2011), which is where the majority of those arriving in Southern Europe are from nowadays.

Nonetheless, the current media and systematic representation do not seem to be so clear, especially when the main actors are mostly refugees or asylum seekers, rather than economic immigrants. In the current European context, with the continent in the middle of an unprecedented migratory crisis, Western media coverage of migration and refuge seems to diverge, depending mostly on the social, demographic, political, and economic context of the audience in the region (Pantti, 2016). Even though images in European media are expected to continue to depict refugees in a negative way, as they previously did with immigrants (Esses et al., 2008; Nightingale; Goodman; Parker, 2017), this is not always true.

This is confirmed by recent studies that have analyzed the representation of migrants and/or refugees, in both text and images. During the current migratory crisis, Central or Eastern Europe media outlets continue to associate refugees with a notion of threat to the security and economy of the country. This happens particularly in Austrian media (Greussing; Boomgaarden, 2017), as well as in Czech and Slovakian media (Kovář, 2019). This negative coverage is also present out- 
side European borders, such as in Israeli media, which not only represent refugees as a security threat but also seem to reify them using formal photographic techniques (Tirosh; Klein-Avraham, 2019). Canadian media also represent immigrants as criminals or terrorists, although, in this case, the victimization frame comes into play (Stelian, 2014). On the other hand, some European media seem to show solidarity with refugees, as the Spanish media did for example at the beginning of the refugee crisis (López-del-Ramo; Humanes, 2016). Moreover,

Zhang and Hellmueller (2017) defend that there was a turning point in media coverage of the migratory crisis after 2015, after the publication in September of Aylan Kurdi's picture, the Syrian child lying dead on a Turkish beach, causing great international shock (Nightingale; Goodman; Parker, 2017). These authors highlight the differences between the representations of migration by CNN International and Der spiegel after this publication. While international media depicted refugees in a more humanized way, German media amplified the representation of refugees as a security threat, transmitting the need to control and decrease the presence of refugees in images while increasing the presence of security forces. This change in informative frames after 2015 has also been pointed out by other authors, such as Lenette and Cleland (2016) or Greenwood and Thomson (2020), although they describe the changing frames not only as notions of symbolic or real threats, but also in terms of a potential burden, as the photographs seem to be loaded with large amounts of people fleeing wars or persecution, located at borders or on boats (Greenwood; Thomson, 2020). These denotative elements frequently transmit two main ideas, namely displaced people as victims and a burden to society.

These examples illustrate the heterogeneity, complexity, and variability of the media coverage of the migratory crisis, depending on the sociodemographic features and migratory pressures of different regions. Furthermore, this review allows us to conclude that the most recurrent frames in the media, at both a textual and visual level, are the following: those that represent migrants and refugees in a human and normalized way, those that depict them as victims, as an economic burden for the hosting society, and as a threat to security, as well as to the social and cultural values of Western societies. Nonetheless, as mentioned above, these frames vary depending on the media outlet and the social, political, and economic context of each country, as well as the editorial and ideological aims of each media outlet or institution.

For this reason, the present study analyzes the connotative representations of immigrants and refugees transmitted by Southern European mass media, focusing on four visual frames defined in previous studies (Amores; Arcila-Calderón; Stanek, 2019; Amores; Arcila-Calderón; González-de-Garay, 2020):

- normalization,

- victimization,

- burden, and

- threat.

Among these, it is understood that the two negative frames are burden and threat, which can promote reification and dehumanization of immigrants and refugees (Stelian, 2014), as well as a potential increase in feelings of fear within host societies, which at the same time could lead to behaviors that attack the social welfare of immigrants and refugees. Nevertheless, although the normalization and victimization frames can have a more positive effect on these feelings and attitudes, this has yet to be confirmed, and in fact some studies suggest that frames that victimize migrants also tend to contribute to their dehumanization (Stelian, 2014), despite being able to improve positive attitudes by increasing empathy and positive emotions (Parrott et al., 2019). Meanwhile, the normalization frame is considered to depict displaced people in the most humanized way, but the effect on societal opinion could indeed be the opposite, generating a negative response in the audience due to comparisons mediated by initial prejudices or lack of empathy. However, these effects still need to be proven empirically, as is planned in later phases of this research.

As mentioned above, the main goal of this study is to explore the way in which immigrants and refugees are connotatively depicted in images used by Southern European media during the migration crisis in Europe and the Mediterranean, with the aim of identifying potential differences between the three most affected countries - Spain, Italy and Greeceas well as possible changes in media coverage over time. Thus, according to the review, there has been an increase in negative feelings and attitudes, as well as a rejection of displaced people since the beginning of the crisis, along with views that consider migrants and refugees as a burden on or threat to the host societies. Furthermore, the incidence of hate crimes in the three countries studied has continuously increased over recent years, possibly due to an increasingly negative media and institutional discourse (Vollmer; Karakayali, 2018; Esses; Hamilton; Gaucher, 2017). Even though representations of refugees tend to be more divergent and benevolent than that of immigrants, this representation also seems to have worsened in recent years, especially after 2015, when the migratory crisis deteriorated and requests for asylum rapidly increased (Amores; Arcila-Calderón; Stanek, 2019). For this reason, the following hypothesis is proposed:

$\mathrm{H} 1$ : There has been a temporal increase in the presence of negative connotative visual frames of immigrants and refugees in Southern European media since the beginning of the migratory crisis. 
Furthermore, despite this negative trend in the attitudes of citizens and the representation of migration in European media, as mentioned above, this does not occur similarly in each region; the most apprehensive attitudes have developed in the areas most affected by the massive arrival of immigrants (Hangartner et al., 2017; Hopkins, 2010). At the same time, media coverage of the migratory crisis seems to be conditioned by contextual elements. Thus, the most negative representations of displaced people occur are presented by media outlets located in the geographic areas most affected by the migratory crisis, or in areas with specific sociopolitical and economic circumstances, such as some Central and Eastern European countries. This has been proven by several studies that identify a more negative and biased coverage of the migratory crisis in the media in Germany compared with other countries that are less affected by migratory pressure, perhaps due to Germany receiving the largest number of asylum requests per year (Zhang; Hellmueller, 2017; Amores; Arcila-Calderón; Stanek, 2019). Bearing this and the different attitudes and perceptions towards migration in each territory in mind, we expect to find statistical differences between the perceived representation of immigrants and refugees in the three Southern European countries analyzed in this work. We thus present the following hypothesis:

$\mathrm{H} 2$ : There are differences in the presence of negative visual frames of immigrants and refugees transmitted in different Southern European countries during the migratory crisis.

Finally, the coverage seems to be dependent not only on the geographical context but also on the ideological aim of each media outlet and institution. This is shown by the fact that the most negative informative frames about migration are not only sourced from media in countries with high migratory pressure but also those in which anti-immigration discourses and policies are most well accepted. For this reason, alongside national differences, it is important to explore the potential differences between media outlets, given that the coverage of the crisis might be more influenced by the editorial line of each media outlet than by the country in which it is located. Bearing this in mind, the following research question is posed:

RQ1: Are there differences in the presence of negative visual frames of immigrants and refugees transmitted by each of the analyzed media?

\section{Methods}

\subsection{Sample}

Content analysis was conducted to examine the connotative visual frames of immigrants and refugees in the main news media in the Southern European countries most affected by the consequences of the migratory crisis. Content analysis is one of the most reliable quantitative tools for studying news coverage and the representation of social actors in the media (Neuendorf, 2002). Therefore, the unit of analysis in this article is each of the informative photographs depicting immigrants and/or refugees published between 2014 and 2019 by digital versions of the most representative mass media in Spain, Italy, and Greece. The specific media were selected using the following criteria: (i) a well-known, general information media outlet with the largest possible number of readers, (ii) with a digital platform, preferably recognized by Google News, (iii) with relevant use of photography, (iv) a large distribution, transcendence, and influence in European public opinion, and finally, $(\mathrm{v})$ with the presence of different editorial lines, contributing to the end goal of collecting a reliable and representative sample of different content focused on migration and asylum seekers published in each country.

According to these requirements, the final selection for each of the countries included: El país and El mundo in Spain, La repubblica and Corriere della sera in Italy, and Ta nea, To vima, and Kathimerini in Greece. For the Greek media, images from three digital media outlets were used: a leading conservative newspaper, Kathimerini, and two outlets with center-left editorial lines, added to contrast with the previous one. This was necessary given that none of the more progressive media had a large enough sample size during the years in question. With this in mind, photographs for the sample in each year were selected, taking care to maintain the same representation in each media outlet.

Once the media outlets had been selected, photographs were collected through Google News and temporal search criteria for each of the chosen media outlets, within a time range of one year from 2014. Boolean operators were used to search the site within the determined time range. In short, to locate the specific content on immigrants and refugees, the search was carried out using predefined keywords in each of the three languages. The terms used were the following: refuge, migration, immigration, refugee (masculine, feminine, singular, and plural forms), migrant/s, immigrant/s. However, for one of the media outlets, El mundo, images could not be collected through Google News, since it was no longer included in the news aggregator portal in recent years. For this reason, photographs from this outlet were compiled directly from its website, where it offers a library section with a search engine. In this case, the same temporal search strategy was followed using the preestablished terms.

Once the indexed images with the key words in each of the predetermined years had been located, we collected the first ten photographs published each year from each of the media outlets in which immigrants and/or refugees appeared, paying attention to the chronological order of appearance with relevant criteria. For the Greek media outlets, ten images were collected from each year from Kathimerini (conservative) and five from each of the other two media, Ta nea and To vima (center-left). 
Finally, the same number of units of analysis from each media outlet (or editorial line in the Greek case) and country were obtained. In total, a sample of ten images was collected for each media outlet (or editorial line) and year, 20 in each country and year (60 images in total from each media outlet or editorial line, and 120 in each country), contributing to a sample of 60 photographs from each year (2014-2019), with a total of 360 images (Table 4).

Table 4. Distribution of photographs per media outlet and country

\begin{tabular}{|l|c|c|c|c|c|c|}
\hline \multicolumn{1}{|c|}{ Country } & \multicolumn{2}{c|}{ Spain } & \multicolumn{2}{c|}{ Italy } & \multicolumn{2}{c|}{ Greece } \\
\hline Media outlet & El país & El mundo & La repubblica & Corriere della sera & Ta nea/To vima & Kathimerini \\
\hline Photographs & 60 & 60 & 60 & 60 & 60 \\
\hline Country subtotal & \multicolumn{3}{|c|}{120} & & 120 & 120 \\
\hline Total & \multicolumn{2}{|c|}{360} \\
\hline
\end{tabular}

\subsection{Instrument and measures}

To carry out this study, the coding system designed by the authors in previous studies (Amores; Arcila-Calderón; Stanek, 2019; Amores; Arcila-Calderón, 2019) was used, based on the identification model of visual frames proposed by Rodríguez and Dimitrova (2011) that had been inspired by the coding systems previously designed by Zhang and Hellmueller (2017), López-del-Ramo and Humanes (2016), and Muñiz et al. (2006). Given that the goal of this work is to examine the implicit representation of displaced people transmitted in photographs and disseminated through Southern European media, and that the original instrument had three blocks including the analysis of the stylistic, denotative, and connotative dimensions of the images, for this work only the connotative analysis block was used. This block makes it possible to identify the four predefined connotative visual frames (normalization, victimization, burden, and threat) in the images of immigrants and refugees based on various attributes of their symbolic representation. Thus, the categorical system used for this work is divided into two main sections. The first is dedicated to the basic identification data of the photograph (identification number, country of reference, news medium, and year of publication), while the second section is dedicated to the analysis of the connotative dimension of the photographs (the third level of visual framing analysis). This section of connotative analysis, in turn, has four scales corresponding to each of the visual frames, each comprising eight connotative attributes, operationalized as dichotomous variables which may or may not be identified within the displaced persons portrayed in the photographs. Below is a summary of the categories that make up the coding system, as well as the attributes that make up the connotative representation frames:

A. Identification data

A.1. Photograph number

A.2. Coder number

A.3. Country

A.4. Media outlet

A.5. Year

B. Connotative analysis of the photograph

In this section, the underlying connotative representation of immigrants and/or refugees is studied. To do this, four groups of eight dichotomous and accumulative variables were defined, with matching attributes implicitly connected to each of the predefined visual frames.

B.1. Normalization frame: This identifies whether the immigrant/refugee is presented as: 1=Humble/modest; 2=Honorable/supportive; 3=Open/tolerant; 4=Familiar/close; 5=Affable/friendly; 6=Integrated/adapted; 7=Hard-working/responsible; 8=Skillful/intelligent

B.2. Victimization frame: This identifies whether the immigrant/refugee is presented as: 1=Victim/innocent; 2=Vulnerable/defenseless; 3=Needy; 4=Excluded; 5=Stigmatized; 6=Wretched; 7=Miserable; 8=Martyr

B.3. Burden frame: This identifies whether the immigrant/refugee is presented as: 1=Potential burden; 2=Misfit; 3=Clumsy/uneducated; 4=Lazy; 5=Homeless; 6=Rude; 7=Profit-seeking; 8=Undocumented/illegal

B.4. Threat frame: This identifies whether the immigrant/refugee is presented as: 1=Potential threat; 2=Intolerant; 3=Conflictive; 4=Rebel/subversive; 5=Offender; 6=Fanatic/extremist; 7=Islamist; $8=$ Terrorist

The internal consistency of the connotative analysis section was acceptable for each of the predefined frames; specifically, the reliability coefficients of the scales were .82 for the normalization frame, .81 for the victimization frame, .77 for the burden frame, and .78 for the threat frame. In addition, the instrument showed acceptable average intercoder reliability $\left(\alpha_{k}=.71\right)$, as tested using the original instrument with three external coders. Specifically, once the mean of the reliability of each of the dichotomous categories was obtained, the level of agreement between the different frames was .75 for the normalization frame, .62 for the victimization frame, .70 for the burden frame, and .77 for the threat frame. In this regard, although the current work focuses mainly on the negative frames (burden and threat) and the average 
Table 5. Intercoder reliability of the items in each visual frame

\begin{tabular}{|c|c|c|c|c|c|c|c|}
\hline \multicolumn{8}{|c|}{ Normalization frame $\left(a_{k}=.75\right)$} \\
\hline Humble/ modest & $\begin{array}{l}\text { Honorable/ } \\
\text { supportive }\end{array}$ & Open/ tolerant & Familiar/ close & $\begin{array}{l}\text { Affable/ } \\
\text { friendly }\end{array}$ & $\begin{array}{l}\text { Integrated/ } \\
\text { adapted }\end{array}$ & $\begin{array}{l}\text { Hard-working / } \\
\text { responsible }\end{array}$ & $\begin{array}{c}\text { Skillful/ } \\
\text { intelligent }\end{array}$ \\
\hline .583 & .843 & .732 & .784 & .753 & .855 & .757 & .683 \\
\hline \multicolumn{8}{|c|}{ Victimization frame $\left(a_{k}=.62\right)$} \\
\hline Victim/ innocent & $\begin{array}{l}\text { Vulnerable/ } \\
\text { defenseless }\end{array}$ & Needy & Excluded & Stigmatized & Wretched & Miserable & Martyr \\
\hline .576 & .652 & .679 & .748 & .762 & .584 & .526 & .418 \\
\hline \multicolumn{8}{|c|}{ Burden frame $\left(a_{k}=.70\right)$} \\
\hline Potential burden & Misfit & $\begin{array}{l}\text { Clumsy/ une- } \\
\text { ducated }\end{array}$ & Lazy & Homeless & Rude & Profit-seeking & $\begin{array}{c}\text { Undocumen- } \\
\text { ted /illegal }\end{array}$ \\
\hline .892 & .693 & .814 & .654 & .566 & .834 & .542 & .588 \\
\hline \multicolumn{8}{|c|}{ Threat frame $\left(a_{k}=.77\right)$} \\
\hline Potential threat & Intolerant & Conflictive & $\begin{array}{c}\text { Rebel/ } \\
\text { subversive }\end{array}$ & Offender & $\begin{array}{c}\text { Fanatic/ extre- } \\
\text { mist }\end{array}$ & Islamist & Terrorist \\
\hline .776 & .624 & .727 & .683 & .834 & .825 & .831 & .884 \\
\hline
\end{tabular}

level of agreement of the entire connotative block is good, the corresponding figure for the victimization frame does not reach the minimum threshold acceptable in the Social Sciences (.67), thus it should be noted that the results related to this frame should be interpreted with a degree of caution. The intercoder reliability of each of the items that make up the four frames is presented in Table 5.

Finally, to obtain a quantitative indicator of the predominance of each connotative frame in the analyzed photographs and media outlets, new variables were calculated by adding the values of the dichotomous categories that compose each of these frames. As each block had the same number of items, it was not necessary to standardize these measurements. Thus, the new variable capturing the predominance of each frame uses a scale from 0 to 8 , where 0 corresponds to no presence of any of the eight possible connotative attributes and 8 corresponds to all the attributes identified in the unit of analysis, which would be the highest level of presence of the connotative frame.

Thereafter, the average presence of each of the frames by country, media outlet, and year was compared using the one-factor analysis of variance (Anova) statistical test to evaluate the hypotheses proposed above and answer the research question. Thus, in the descriptive analysis, it was considered that the identification of only one of the attributes of a connotative frame would indicate the inclusion of the frame in the unit of analysis, while for the inferential analysis, the prevalence scales of the frames were used.

The coverage seems to be dependent not only on the geographical context but also on the ideological aim of each media outlet and institution

\section{Results}

Although the present work focuses on an analysis of the negative connotative visual frames of immigrants and refugees transmitted by Southern European media, which are expected to have increased in recent years, in order to capture more broadly the evolution and differences among media outlets and countries, the results were extracted for all the predefined connotative frames. Thus, in the first place and at a descriptive level, the frequency of images with each of the frames is presented, including the photographs in which the presence of at least one of the connotative attributes was perceived. Note that the same photograph can transmit multiple connotative representations at the same time, thus encoding the attributes of different frames in the same unit of analysis.

In this regard, the most common frame that appeared in the analyzed photographs was victimization, with $81.7 \%$ (294 photographs), followed by burden, with $75.8 \%$ (273 photographs). The normalization frame appeared in 182 photographs (50.6\%), and threat in 180 (50\%), generally maintaining a similar presence. Regarding the evolution of this frequency distribution, a priori, there seems to be a significant increase in images with negative connotative attributes, for both burden and threat (Table 6).

Table 6. Distribution of percentages of images for each connotative visual frame and year

\begin{tabular}{|l|c|c|c|c|c|c|}
\cline { 2 - 6 } \multicolumn{1}{c|}{} & $\mathbf{2 0 1 4}$ & $\mathbf{2 0 1 5}$ & $\mathbf{2 0 1 6}$ & $\mathbf{2 0 1 7}$ & $\mathbf{2 0 1 8}$ \\
\hline Normalization & $55 \%$ & $41.7 \%$ & $58.3 \%$ & $63.3 \%$ & $38.3 \%$ & $85 \%$ \\
\hline Victimization & $85 \%$ & $78.3 \%$ & $80 \%$ & $76.7 \%$ & $78.3 \%$ \\
\hline Burden & $40 \%$ & $68.3 \%$ & $76.7 \%$ & $75 \%$ & $95 \%$ & $700 \%$ \\
\hline Threat & $21.7 \%$ & $48.3 \%$ & $40 \%$ & $50 \%$ & $70 \%$ \\
\hline
\end{tabular}


However, breaking down these percentages by country, this evolution already presents divergences at a descriptive level (Graph 1). While there is a high and stable percentage of images where the attributes of victimization are detected in all countries, this does not occur with the rest of the frames, since the percentage of burden photographs in Greece is constantly higher than those containing victimization attributes, while the images with a threat frame increase in 2015 , as well as in the final 2 years of the analysis. In Spain and Italy, both the burden and threat frames appear to increase gradually over the years.

The same occurs when exploring the distribution of percentages of the connotative frames by analyzed media outlet. A priori, differences are perceived between the media, even within each country (Graph 2). These differences suggest a higher percentage of images with burden and threat frames in media with a more conservative editorial line, although all the media show an increase in images with negative frames over the years.

Furthermore, the frequency distribution of the connotative attributes that make up each of the frames was explored to identify those that have increased the most in the images analyzed. In this regard, the attributes that stand out the most in the normalization frame are those that reflect the displaced as modest or humble, familiar or close, and integrated or adapted. In the case of the victimization frame, the attributes that stand out are those that portray the immigrant as needy, wretched, vulnerable, or defenseless, and as a victim or innocent. However, the frequency of all the attributes re-

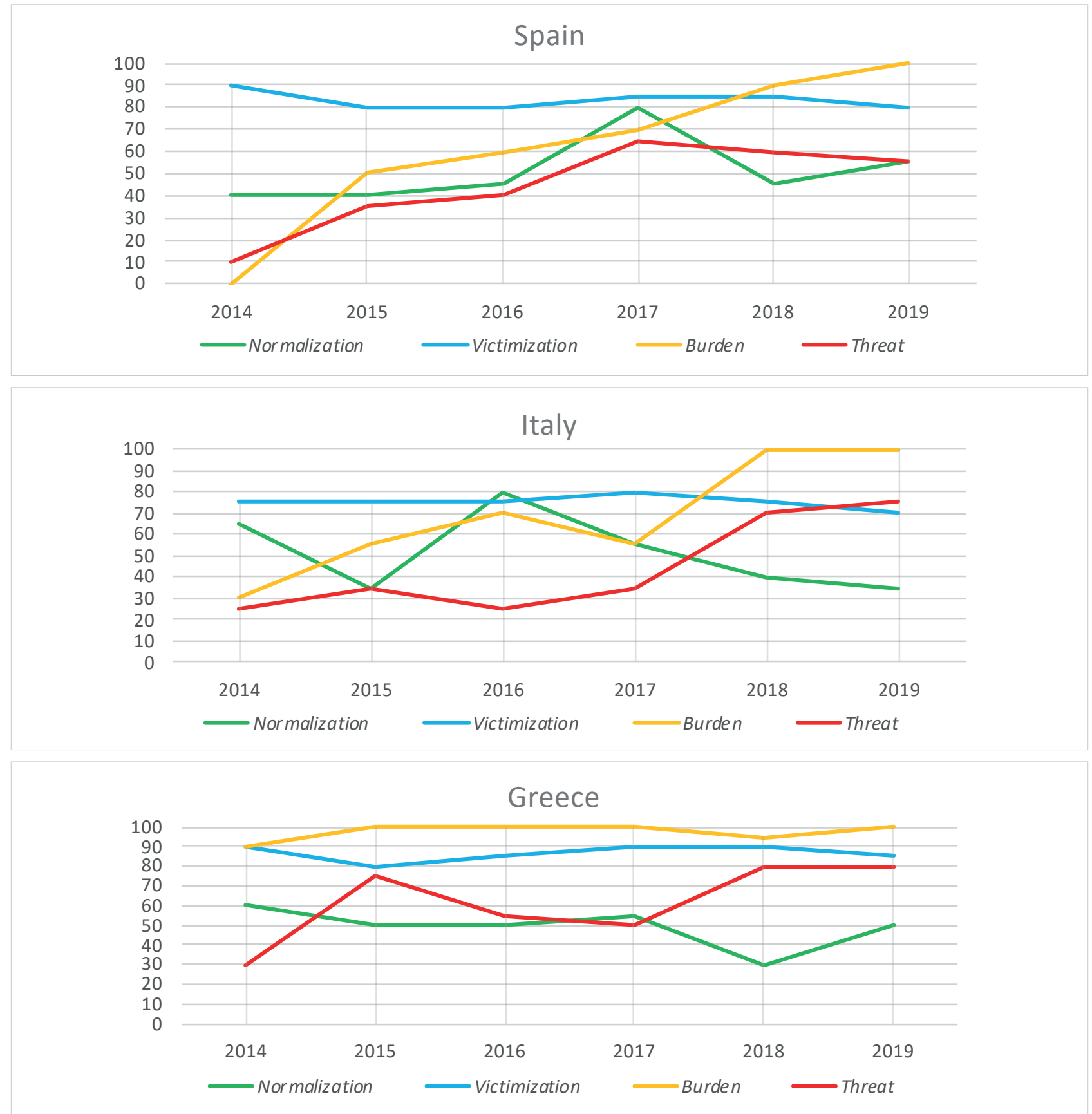

Graph 1. Evolution of the percentage of images with each connotative visual frame depicting immigrants and refugees in Southern European countries from 2014 to 2019 
mains relatively constant through the years. This does not occur with the negative frames, where a gradual increase in all their attributes is perceived. In the case of the burden frame, the items that stand out are those that show the displaced person as a potential burden, as undocumented, illegal or without papers, as a misfit, and as a homeless person. Finally, regarding the threat frame, the attributes with the highest percentage are those that define the immigrant as a potential threat, as a conflictive, rebellious, or subversive person, or as an offender. In both cases, the aforementioned attributes are also those that exhibit the greatest increase over the years. The evolution of these attributes is shown in Graph 3.

Once this initial exploration has been carried out, it is possible to conduct an inferential verification of the proposed hypotheses based on a comparison of means. To do this, we used the variables that were applied to record each of the frames based on the sum of the connotative attributes present in the photographs.

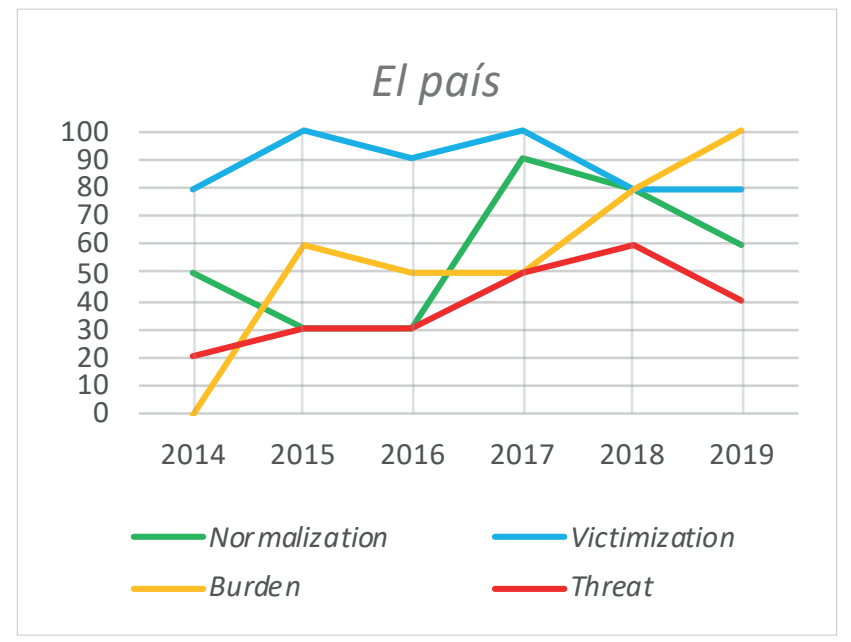

\section{La repubblica}

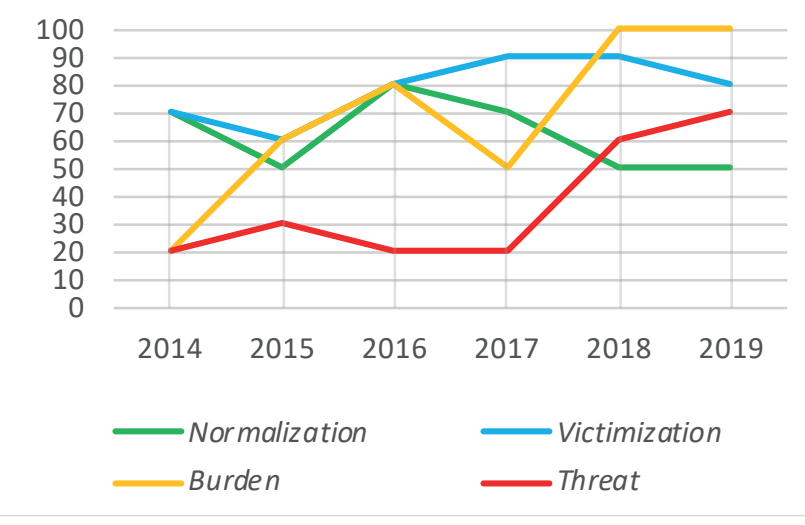

\section{Ta nea and To vima}

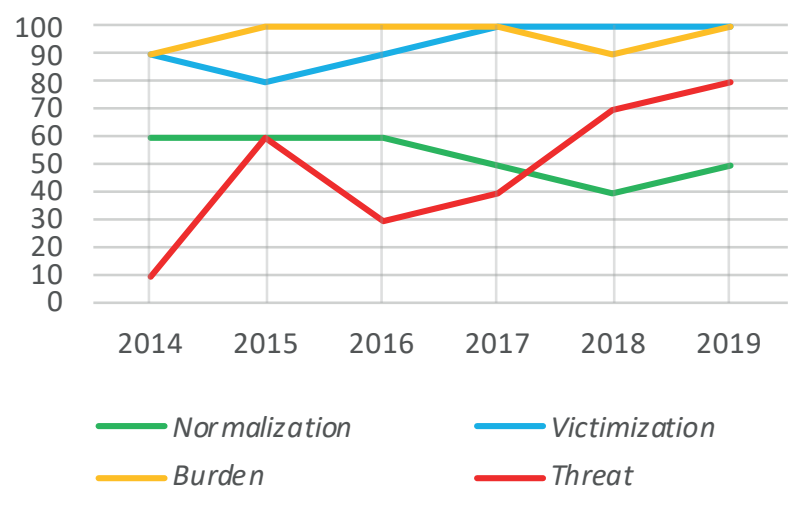

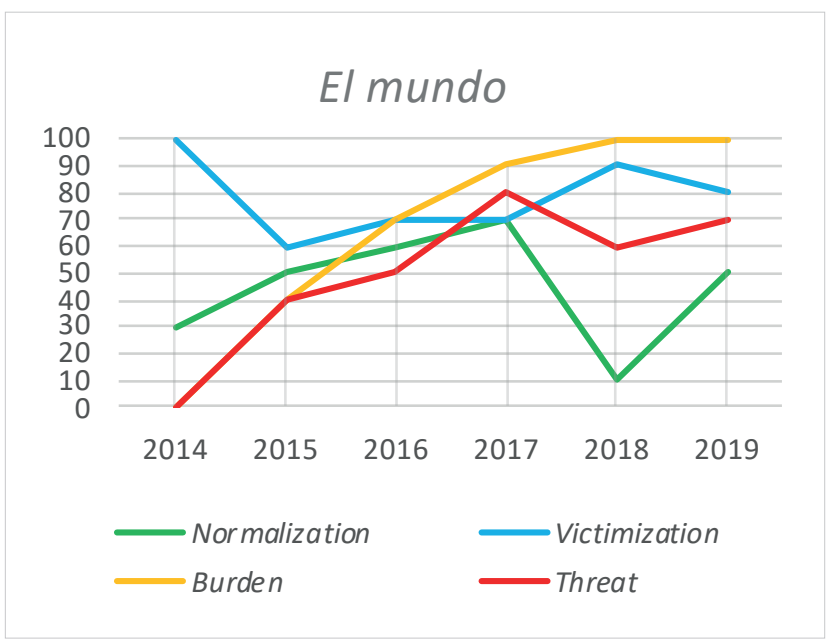

\section{Corriere della sera}

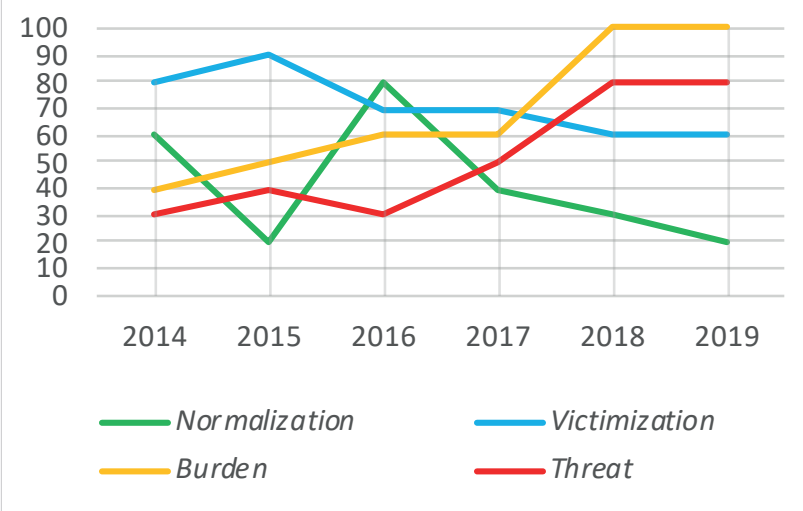

\section{Kathimerini}

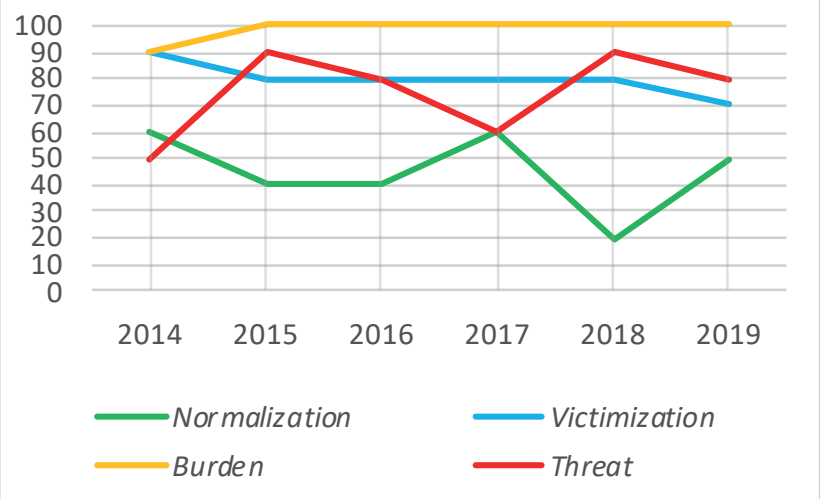

Graph 2. Evolution of the percentage of images with each connotative visual frame depicting immigrants and refugees in Southern European main media from 2014 to 2019 


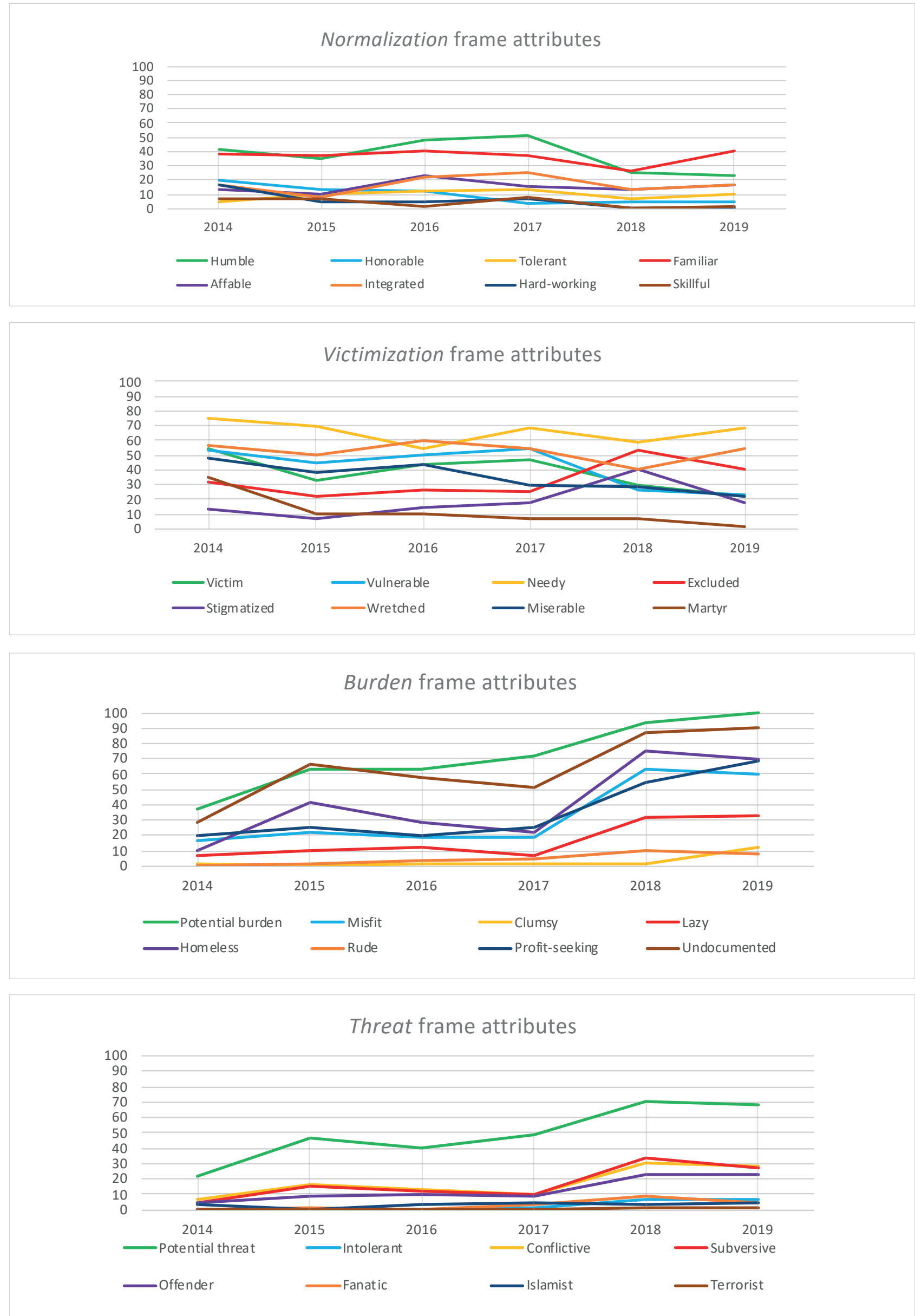

Graph 3. Evolution of the percentage presence of each connotative attribute corresponding to each visual frame in the studied images depicting immigrants and refugees from Southern European countries from 2014 to 2019 
Presence of visual frames by year

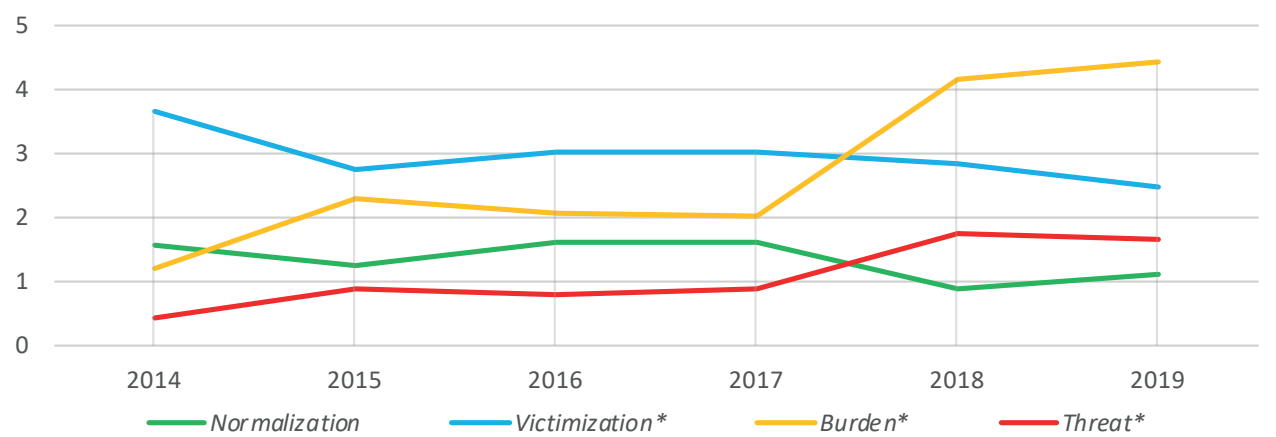

Graph 4. Comparison of presence of visual frames of immigrants and refugees by year

Regarding $\mathrm{H} 1$, which posits a temporal increase in the presence of negative visual frames of immigrants and refugees in Southern European media since the beginning of the migratory crisis, there were indeed temporal differences in both negative frames, i.e., burden $\left[F(5,354)=34.281, p<.01, \eta^{2}=.308\right]$ and threat $\left[F(5,354)=9.216, p<.01, \eta^{2}=.115\right]$, as well as the victimization frame $[F(5$, $\left.354)=2.24, p<.05, \eta^{2}=.031\right]$, although in the latter case, there are only significant differences between the first (2014) $(M=3.68$, $S D=2.45)$ and last year (2019) of the study $(M=2.5, S D=1.86)$, with a large effect size $[t(354)=3.113, p<.05, d=0.748]$.

Regarding the burden frame, significant differences were identified between $2014(M=1.2, S D=1.78)$ and 2015 $(M=2.3, S D=1.91)$, with a moderate effect size $[t(354)=3.264, p<.05, d=0.596]$, and between 2014 and $2018(M=4.17$, $S D=1.67)[t(354)=9.42, p<.01, d=1.721], 2014$ and $2019(M=4.42, S D=1.6)[t(354)=10.411, p<.01, d=1.902], 2015$ and $2018[t(354)=5.709, p<.01, d=1.042], 2015$ and $2019[t(354)=6.596, p<.01, d=1.203], 2016(M=2.05, S D=1.88)$, and $2018[t(354)=6.514, p<.01, d=1.192], 2016$ and $2019[t(354)=7.42, p<.01, d=1.358], 2017(M=2.02, S D=1.86)$ and 2018 $[t(354)=6.656, p<.01, d=1.216]$, and between 2017 and $2019[t(354)=7.571, p<.01, d=1.383]$, all with a large effect size.

Regarding the threat frame, significant differences were found between $2015(M=0.88, S D=1.19)$ and 2019 ( $M=1.65$, $S D=1.71)[t(354)=3.105, p<.05, d=0.523]$, between $2016(M=0.78, S D=1.19)$ and $2019[t(354)=3.51, p<.01, d=0.591]$, and between $2017(M=0.87, S D=1.189)$ and 2019 [ $t(354)=3.17, p<.05, d=0.529]$, all of them with a medium size effect, and between $2014(M=0.42, S D=0.93)$ and $2018(M=1.77, S D=1.72)$ [ $t(354)=5.466, p<.01, d=0.976], 2014$ and 2019 $[t(354)=4.992, p<.01, d=0.894], 2015$ and $2018[t(354)=3.372, p<.01, d=0.602], 2016$ and $2018[t(354)=3.98, p<.01$, $d=0.669$ ], and between 2017 and 2018 [t(354)=3.644, $p<.01, d=0.609]$, all with a large effect size.

These results, which are visualized in Graph 4, confirm $\mathrm{H} 1$, as they prove an increase in the presence of negative frames in recent years.

Secondly, $\mathrm{H} 2$ posits the existence of differences in the presence of negative frames transmitted in the different Southern European countries. In this case, statistically significant differences were also detected in both negative frames, i.e., burden $\left[F(2,357)=36.646, p<.01, \eta^{2}=.170\right]$ and threat $\left[F(2,357)=5.45, p<.01, \eta^{2}=.029\right]$. Significant differences were also observed in the victimization frame $\left[F(2,357)=10.799, p<.01, \eta^{2}=.057\right]$, between Spain $(M=3.63, S D=2.26)$ and Italy $(M=2.89, S D=2.18)$, with a moderate effect size $[t(357)=2.776, p<.05, d=0.333]$, and between Spain and $G$ reece $(M=2.41$, $S D=1.62)$, with a large effect size $[t(357)=4.610, p<.01, d=0.620]$.

For the burden frame in particular, differences were detected between Spain $(M=2.01, S D=2.20)$ and $G$ reece $(M=3.93$, $S D=1.63)[t(357)=7.639, p<.01, d=0.991]$, and between Italy $(M=2.13, S D=1.97)$ and Greece $[t(357)=7.143, p<.01$, $d=0.995]$, both with a large effect size. Regarding the threat frame, significant differences were found between Spain $(M=0.89, S D=1.26)$ and Greece $(M=1.41, S D=1.63)[t(357)=2.841, p<.05, d=0.357]$, and between Italy $(M=0.88, S D=1.32)$ and Greece $[t(357)=2.917, p<.05, d=0.357]$, both with a moderate effect size.

These results also confirm $\mathrm{H} 2$, since they represent statistically significant differences in the predominance of negative frames in the analyzed countries. Although such a difference is not perceived between Spain and Italy, both of these countries present differences compared with the Hellenic nation, where the presence of both negative frames is greater. These differences are presented in detail in Table 7.

Table 7. A comparison of the presence of visual frames of immigrants and refugees among the analyzed countries

\begin{tabular}{|c|c|c|c|c|c|c|}
\hline & \multicolumn{2}{|c|}{ Spain } & \multicolumn{2}{|c|}{ Italy } & \multicolumn{2}{|c|}{ Greece } \\
\hline & M & SD & M & SD & M & SD \\
\hline Normalization & 1.43 & 1.80 & 1.42 & 1.94 & 1.21 & 1.69 \\
\hline Victimization * & 3.63 & 2.26 & 2.89 & 2.18 & 2.41 & 1.62 \\
\hline Burden * & 2.01 & 2.20 & 2.13 & 1.97 & 3.93 & 1.63 \\
\hline Threat* & 0.89 & 1.26 & 0.88 & 1.32 & 1.41 & 1.63 \\
\hline
\end{tabular}


Finally, a research question was posed regarding the existence of possible differences in the presence of negative visual frames of immigrants and refugees among the analyzed media. In this case, as expected, once again significant differences were found in both negative frames, i.e., burden $\left[F(5,354)=15.351, p<.01, \eta^{2}=.178\right]$ and threat $\left[F(5,354)=5.11, p<.01, \eta^{2}=.067\right]$, as well as for the victimization frame $\left[F(5,354)=6.927, p<.01, \eta^{2}=.089\right]$, in this case between El país $(M=4.05, S D=2.13)$ and Corriere della sera $(M=2.77, S D=2.34)$, with a moderate effect size $[t(354)=3.486, p<.01, d=0.572]$, and between El país and Ta nea and To vima $(M=2.88, S D=1.70)[t(354)=3.171, p<.05, d=0.607]$, between El país and Kathimerini $(M=1.93, S D=1.40)$ $[t(354)=5.753, p<.01, d=1.177]$, between El mundo $(M=3.2, S D=2.33)$ and Kathimerini $[t(354)=3.443, p<.01, d=0.661]$, and between La repubblica $(M=3.02, S D=2.03)$ and Kathimerini $[t(354)=2.943, p<.05, d=0.625]$, all with a large effect size.

For the burden frame specifically, significant differences were found between $E$ l país $(M=1.93, S D=2.21)$ and Ta nea and To $\operatorname{vima}(M=3.62, S D=1.69)[t(354)=4.728, p<.01, d=0.859]$, between El país and Kathimerini $(M=4.25, S D=1.51)[t(354)=6.508$, $p<.01, d=1.226]$, between $E I$ mundo $(M=2.08, S D=2.21)$ and Ta nea and To vima $[t(354)=4.306, p<.05, d=0.783]$, between $E I$ mundo and Kathimerini $[t(354)=6.087, p<.01, d=1.147]$, between La repubblica $(M=2.17, S D=2.05)$ and Ta nea and To vima $[t(354)=4.073, p<.01, d=0.772]$, between La repubblica and Kathimerini $(M=1.93, S D=1.40)[t(354)=5.851, p<.01, d=1.155]$, between Corriere della sera $(M=2.1, S D=1.91)$ and Ta nea and To vima $[t(354)=4.261, p<.01, d=0.843]$, and between Corriere della sera and Kathimerini $[t(354)=6.039, p<.01, d=1.249]$, all with a large effect size.

Regarding the threat frame, significant differences were found between $E$ I mundo $(M=1.05, S D=1.33)$ and Kathimerini $(M=1.85, S D=1.77)[t(354)=3.149, p<.05, d=0.511]$, between Corriere della sera $(M=0.98, S D=1.23)$ and Kathimerini $[t(354)=3.413, p<.01, d=0.571]$, and between Ta nea and To vima $(M=0.97, S D=1.34)$ and Kathimerini $[t(354)=3.476$, $p<.01, d=0.561]$, with a moderate effect size; and between $E$ l país $(M=0.73, S D=1.16)$ and Kathimerini $[t(354)=4.398$, $p<.01, d=0.748]$, and between La repubblica $(M=0.78, S D=1.42)$ and Kathimerini $[t(354)=4.201, p<.01, d=0.667]$, both with a large effect size. The differences between the means are presented in Table 8.

These results confirm that there are indeed differences between the different media in Southern Europe in the way they connotatively represent immigrants and refugees. The Greek media outlet Kathimerini stands out regarding both negative frames, with a greater presence of negative frames than the other analyzed media. Similarly, this medium has the lowest presence of the victimization frame. Thus, as pointed out in the initial review, the differences seem to indicate a greater presence of negative frames in media with a more conservative editorial line, even in media from the same country, such as Greece, since Kathimerini shows a significantly higher presence of the threat frame when compared with the two center-left media in the same country, Ta nea and To vima.

Table 8. Comparison of the presence of visual frames of immigrants and refugees among the analyzed media

\begin{tabular}{|c|c|c|c|c|c|c|c|c|c|c|c|c|}
\hline & \multicolumn{2}{|c|}{ Elpaís } & \multicolumn{2}{|c|}{ El mundo } & \multicolumn{2}{|c|}{ La repubblica } & \multicolumn{2}{|c|}{ Corriere della sera } & \multicolumn{2}{|c|}{ Ta nea/To vima } & \multicolumn{2}{|c|}{ Kathimerini } \\
\hline & $\mathbf{M}$ & SD & $\mathbf{M}$ & SD & M & SD & $\mathbf{M}$ & SD & $\mathbf{M}$ & SD & $\mathbf{M}$ & SD \\
\hline Normalization & 1.55 & 1.81 & 1.30 & 1.81 & 1.82 & 2.18 & 1.02 & 1.59 & 1.35 & 1.76 & 1.07 & 1.60 \\
\hline Victimization * & 4.05 & 2.13 & 3.20 & 2.33 & 3.02 & 2.03 & 2.77 & 2.34 & 2.88 & 1.70 & 1.93 & 1.40 \\
\hline Burden * & 1.93 & 2.21 & 2.08 & 2.21 & 2.17 & 2.05 & 2.10 & 1.91 & 3.62 & 1.69 & 4.25 & 1.51 \\
\hline Threat * & 0.73 & 1.16 & 1.05 & 1.33 & 0.78 & 1.42 & 0.98 & 1.23 & 0.97 & 1.34 & 1.85 & 1.77 \\
\hline
\end{tabular}

\section{Discussion and conclusions}

The results of this study confirm that, in general, although the dominant frame within the analyzed images is victimization, followed by burden, there is a temporal increase in the presence of connotative visual frames that negatively represent immigrants and refugees in Southern European media. From the analysis, it is clear that both the burden and threat frames have not stopped increasing in the recent years of the migratory crisis. In the exploratory analysis, a slight, one-off increase in these frames is also observed in 2015, the year in which the numbers of asylum applications in Europe increased exponentially. However, this does not imply a statistically significant increase, since there are no differences in the surrounding years. The same occurs, but inversely, with the victimization frame, which seems to decrease in that year, which would make sense, but this decrease is not significant in statistical terms, and it should be noted that the intercoder reliability of the construct measuring this frame did not reach the accepted minimum. In sum, it has been found that, while the presence of negative frames has increased in the analyzed countries, especially since 2018 , the victimization frame seems to have gradually decreased since the beginning of the crisis until last year, with significant differences in this frame between 2014 and 2019, while the normalization frame has remained low but constant over time. This contribution is directly related to the increase in negative attitudes and the rejection of displaced people detected in the analyzed countries. Similarly, these findings can be linked to the general increase in hate speech within these countries, as well as other types of hate crimes which, on specific occasions, can lead to major crimes, as explained in previous sections. 
Secondly, it is confirmed that there are differences between the analyzed Southern European countries regarding their visual representations of immigrants and refugees in the media. Even though the coverage seems to be broadly similar, as the victimization and burden frames stand out above the rest in all the analyzed countries, statistically significant differences were found with regard to the two negative frames, as well as the victi-
The victimization frame shows a greater presence in Spanish than in Greek media, where it has the lowest presence among all three countries. Regarding the negative frames, both are more prevalent in the Greek media mization frame, although, in this case, the results must be interpreted with caution given the limited reliability of the frame. Even so, the latter shows a greater presence in Spanish than in Greek media, where it has the lowest presence among all three countries. Regarding the negative frames, both are more prevalent in the Greek media. However, the frame that stands out is the burden frame, which has also remained practically constant in Greece since the beginning of the crisis. Meanwhile, the threat frame is more present in Greece, although an increase is perceived over time in all three countries. In general terms, the country that shows the most positive depiction of displaced people is Spain, although its coverage is very similar to that of Italy - they only differ in the presence of the victimization frame, with this being higher in Spanish media - while the most negative representation is found in the Greek media. This also fits the information analyzed in the literature review of the perceptions of the citizens of each country and the hate crime figures. The data collected by the Pew Research Center surveys, which explored the percentage of citizens who viewed immigrants and refugees as a potential burden on or threat to their country, directly relate to the results of this study, since Spain is, and has been since the beginning of the crisis, the country with the lowest percentage of citizens with negative attitudes towards migration, followed by Italy and, finally, Greece.

The results of this work confirm that the visual representation of immigrants and refugees differs between Southern European countries and between media outlets themselves. In this regard, differences have been found in the presence of negative frames between most Spanish and Italian media outlets on the one hand, and the Greek outlets on the other. This can be considered to be logical, since we have seen that negative frames stand out much more in Greece than in other countries, especially the burden frame. However, on analyzing the comparisons in detail, not all Spanish and Italian media show differences with Ta nea and To vima, especially in terms of the threat frame, while they do with Kathimerini. In sum, when the conservative Spanish or Italian media are compared with the conservative Kathimerini newspaper, statistically significant differences are perceived, albeit medium-sized. Meanwhile, the center-left media and the Greek conservative media show a large, statistically significant difference. In addition, within the Hellenic state itself, differences were also found between the analyzed media themselves, with Ta nea and To vima having a significantly lower presence of the threat frame than Kathimerini. Thus, at a general level, it can be concluded that Kathimerini is the media outlet with the greatest presence of negative frames, and moreover also stands out for having the lowest presence of the victimization frame. On the other hand, the media outlet with the highest predominance of the victimization frame is the center-left Spanish newspaper El país, which, in turn, presents the lowest predominance of the threat frame in its photographs.

On the one hand, these findings reveal that the representation frames of immigrants and refugees transmitted by Southern European media images are related to feelings and attitudes present in the public opinion of each country. This suggests, in turn, and as speculated in the review, that media may indeed have an emotional and cognitive effect on their audience, either positively or negatively influencing attitudes towards migration and, ultimately, on their conduct and behavior towards these groups. On the other hand, and inversely, it could be speculated that public opinion, as well as sociodemographic circumstances and migratory pressure itself, directly influences the coverage of the refugee crisis in Southern European media. In this sense, it is also important to note that the effects of the arrival of immigrants in Greece were particularly dramatic during the peak of the so-called Mediterranean Refugee Crisis in 2015, not only because of the concentration of arrivals at the main refugee internment camps such as Moria on the Greek island of Lesbos, but also because Greece's socioeconomic situation was the most delicate among all the countries analyzed. This could help to explain the higher proportion of negative frames found in Greek media. However, given that the comparisons between media show differences in frames related to their editorial lines, the results also seem to suggest that the representation of displaced people does not depend only on the social, demographic, and economic contexts of the country, but is also subject to political or ideological intentionality, or the media itself. Thus, as seen when answering the research question, although all media outlets are involved in the increase in negative visual frames transmitted, the proportion of this increase is greater among conservative media, since they promote the most negative representation. The real effect on public opinion could be tested in order to assign greater responsibility to them. What holds true is that all the analyzed media outlets seem to have gradually adapted to such a dehumanizing discourse, making an effort not to show too many images that victimize immigrants, such as portraying them in refugee camps, deserts, and war scenes, and instead beginning to show them at our borders, whether on boats or breaking barbed wire, and often surrounded by security forces. There may be a marked intention to sow in public opinion the representation of migration as a possible burden on or threat to our societies, in order to reduce feelings of moral responsibility and legitimize possible anti-immigration measures, or it may be that this coverage simply responds to news events occurring in each country. Nevertheless, these findings seem to confirm what various studies mentioned during the review have observed since the beginning of the migration crisis: that the representation of immigrants and refugees by Western media seems to diverge depending on the 
socio-demographic, political, and economic contexts of the different regions, but also on the media outlet's editorial line, something that seems to be especially notable since 2015 (Amores; Arcila-Calderón; Stanek, 2019; Greenwood; Thomson, 2020; Lenette; Cleland, 2016; Pantti, 2016; Zhang; Hellmueller, 2017). In this sense, while the Spanish media have been transmitting more positive news frames of displaced people than other Western European countries, as López-del-Ramo and Humanes (2016) have already discovered, media outlets in countries such as Greece that are most strongly affected by migratory pressure (and especially conservative media) seem to be drastically worsening their representation of displaced people in recent years, dehumanizing them and associating them more and more with notions of burden on and/or threat to the host societies, in a similar way to the media in Central and Eastern European countries that have strong anti-immigration policies (Greussing; Boomgaarden, 2017; Kovár̆, 2019). This proves, as Hangartner et al. (2017) or Hopkins (2010) have noted, that the most negative image of migration, as well as the most apprehensive attitudes towards displaced people, tend to develop in geographical areas most affected by the massive arrival of immigrants.

These conclusions open the path to future studies that empirically test the effects of these connotative visual frames of immigrants and refugees on the audience. Similarly, it is deemed necessary to continue exploring these trends in the media representations of displaced people, a group traditionally excluded from and stigmatized in our societies, and to verify whether negative frames continue to increase in the media, not only in Southern Europe but also in the rest of the continent as well, and whether moreover, a priori, positive frames such as victimization are indeed gradually declining. On the other hand, the limitations of the present study should be noted to allow for correction in future works. This work focuses only on the visual frames, therefore no complementary textual content, such as captions or headlines, was included in the analysis. This is due to the fact that the study focused exclusively on images as visual elements with greater impact, but it is possible that the texts accompanying them can modify their interpretation, therefore this analysis could be extended to a broader range of content in future studies. Along the same line, given that this analysis focused on the visual content of images, their metadata, or aspects such as the location of the photographs, were not considered. Thus, it would be interesting for future studies to also address issues such as the possible differences that may exist between images taken within the country where the media outlet is located or elsewhere. On the other hand, the sample is limited to seven news media outlets from the three Southern European countries most affected by the migration crisis. This means that the sample, albeit representative of the content within these countries, is not sufficient to extrapolate the findings to other host European countries. Therefore, it becomes necessary to explore the representation of migration that occurs in the leading media of other European countries. Finally, it would be useful to complement this analysis with a social media study, where it is also possible to directly collect related public opinion, along with other methods that could include machine-learning techniques for the analysis of large volumes of data.

\section{References}

Amores, Javier J.; Arcila-Calderón, Carlos (2019). “Deconstructing the symbolic visual frames of refugees and migrants in the main Western European media". In: Proceedings of the Seventh international conference on technological ecosystems for enhancing multiculturality, pp. 911-918.

https://dl.acm.org/doi/abs/10.1145/3362789.3362896

Amores, Javier J.; Arcila-Calderón, Carlos; González-de-Garay, Beatriz (2020). "The gendered representation of refugees using visual frames in the main Western European media". Gender issues, v. 37, pp. 291-314. https://doi.org/10.1007/s12147-020-09248-1

Amores, Javier J.; Arcila-Calderón, Carlos; Stanek, Mikolaj (2019). "Visual frames of migrants and refugees in the main Western European media". Economics and sociology, v. 12, n. 3, pp. 147-161.

https://doi.org/10.14254/2071-789X.2019/12-3/10

Arcila-Calderón, Carlos; Blanco-Herrero, David; Valdez-Apolo, María-Belén (2020). "Rechazo y discurso de odio en Twitter: Análisis de contenido de los tuits sobre migrantes y refugiados en español". Revista española de investigaciones sociológicas (REIS), v. 172, pp. 21-40.

https://doi.org/10.5477/cis/reis.172.21

Bock, Mary-Angela (2017). "Visual communication effects: Photography”. In: Rössler, Patrick. The international encyclopedia of media effects. New Jersey: John Wiley \& Sons. ISBN: 9781118784044 https://doi.org/10.1002/9781118783764.wbieme0141

Borah, Porismita (2011). "Conceptual issues in framing theory: A systematic examination of a decade's literature". Journal of communication, v. 61, n. 2, pp. 246-263.

https://doi.org/10.1111/j.1460-2466.2011.01539.x 
Burnap, Pete; Williams, Matthew L. (2015). “Cyber hate speech on Twitter: An application of machine classification and statistical modeling for policy and decision making". Policy \& internet, v. 7, n. 2, pp. 223-242.

https://doi.org/10.1002/poi3.85

Burscher, Bjorn; Van-Spanje, Joost; De-Vreese, Claes H. (2015). “Owning the issues of crime and immigration: The relation between immigration and crime news and anti-immigrant voting in 11 countries". Electoral studies, v. 38, pp. 59-69. https://doi.org/10.1016/j.electstud.2015.03.001

Cheng, Lifen; Igartua, Juan-José; Palacios, Elena; Acosta, Tania; Palito, Socorro (2014). “Framing immigration news in Spanish regional press". International migration, v. 52, n. 6, pp. 197-215.

https://onlinelibrary.wiley.com/doi/abs/10.1111/j.1468-2435.2010.00647.x

Colombo, Monica (2018). "The representation of the 'European refugee crisis' in Italy: Domopolitics, securitization, and humanitarian communication in political and media discourses". Journal of immigrant \& refugee studies, v. 16, n. 1-2, pp. 161-178.

https://doi.org/10.1080/15562948.2017.1317896

Contrada, Richard J.; Ashmore, Richard D.; Gary, Melvin L.; Coups, Elliot; Egeth, Jill D.; Sewell, Andrea; Ewell, Kevin; Goyal, Tanya M.; Chasse, Valerie (2001). "Measures of ethnicity-related stress: Psychometric properties, ethnic group differences, and associations with well-being". Journal of applied social psychology, v. 31, pp. 1775-1820.

https://doi.org/10.1111/j.1559-1816.2001.tb00205.x

Corral-García, Alfonso; Fernández-Romero, Cayetano (2015). "Framing y mundo árabe: la cobertura de la prensa española en torno a la revolución tunecina". Estudios sobre el mensaje periodístico, v. 21, n. 2, pp. 793-811. https://doi.org/10.5209/rev_ESMP.2015.v21.n2.50885

Damstra, Alyt; Jacobs, Laura; Boukes, Mark; Vliegenhart, Rens (2019) "The impact of immigration news on anti-immigrant party support: unpacking agenda-setting and issue ownership effects over time". Journal of elections, public opinion and parties, online first.

https://doi.org/10.1080/17457289.2019.1607863

Davidson, Thomas; Warmsley, Dana; Macy, Michael; Weber, Ingmar (2017). "Automated hate speech detection and the problem of offensive language". In: Proceedings of the Eleventh international AAAl conference on web and social media (ICWSM 2017).

http://sdl.soc.cornell.edu/img/publication_pdf/hatespeechdetection.pdf

Dennison, James; Geddes, Andrew (2019). "A rising tide? The salience of immigration and the rise of anti-immigration political parties in Western Europe". The political quarterly, v. 90, n. 1, pp. 107-116.

https://doi.org/10.1111/1467-923X.12620

Eberl, Jakob-Moritz; Meltzer, Christine E.; Heidenreich, Tobias; Herrero, Beatrice; Theorin, Nora; Lind, Fabienne; Berganza, Rosa; Boomgaarden, Hajo G.; Schemer, Christian; Strömbäck, Jesper (2018). "The European media discourse on immigration and its effects: A literature review". Annals of the International Communication Association, v. 42, n. 3, pp. 207-223.

https://doi.org/10.1080/23808985.2018.1497452

Entman, Robert M. (1992). "Blacks in the news: Television, modern racism and cultural change". Journalism quarterly, v. 69, n. 2, pp. 341-361.

https://doi.org/10.1177/10776990920690020

Entman, Robert M. (1993). "Framing: Toward clarification of a fractured paradigm". Journal of communication, v. 43, n. 4, pp. 51-58.

https://doi.org/10.1111/j.1460-2466.1993.tb013 04.x

Esses, Victoria M.; Dovidio, John F.; Semenya, Antoinette H.; Jackson, Lynne M. (2005). "Attitudes towards immigrants and immigration: The role of national and international identity". In: Abrams, Dominic; Hogg, Michael A.; Marques, José M. The social psychology of inclusion and exclusion. Hove: Psychology Press, pp. 317-337. ISBN: 0203595041 https://dl.uswr.ac.ir/bitstream/Hannan/131694/1/Dominic_Abrams\%2C_Michae.pdf\#page=336

Esses, Victoria M.; Hamilton, Leah K.; Gaucher, Danielle (2017). "The global refugee crisis: empirical evidence and policy implications for improving public attitudes and facilitating refugee resettlement". Social issues and policy review, v. 11, n. 1, pp. 78-123.

https://doi.org/10.1111/sipr.12028

Esses, Victoria M.; Veenvliet, Scott; Hodson, Gordon; Mihic, Ljiljana (2008). "Justice, morality, and the dehumanization of refugees". Social justice research, v. 21, n. 1, pp. 4-25.

https://doi.org/10.1007/s11211-007-0058-4 
European Commission (2015). Special Eurobarometer 437. Discrimination in the European Union 2015. https://ec.europa.eu/commfrontoffice/publicopinion/index.cfm/Survey/getSurveyDetail/search/437/surveyKy/2077

European Commission (2018). Special Eurobarometer 469. Integration of Immigrants in the European Union. https://ec.europa.eu/commfrontoffice/publicopinion/index.cfm/Survey/getSurveyDetail/search/469/surveyKy/2169

European Commission (2019a). Special Eurobarometer 493. Discrimination in the European Union. https://ec.europa.eu/commfrontoffice/publicopinion/index.cfm/Survey/getSurveyDetail/search/493/surveyKy/2251

European Commission (2019b). Standard Eurobarometer 92.

https://ec.europa.eu/commfrontoffice/publicopinion/index.cfm/Survey/getSurveyDetail/instruments/STANDARD/yearFrom/2018/yearTo/2020/surveyKy/2255

Fahmy, Shakira (2010). "Contrasting visual frames of our times: A framing analysis of English and Arabic-language press coverage of war and terrorism". International communication gazette, v. 72, n. 8, pp. 695-717.

https://doi.org/10.1177/1748048510380801

Gallego, Mar; Gualda, Estrella; Rebollo, Carolina (2017). "Women and refugees in Twitter: Rhetorics on abuse, vulnerability and violence from a gender perspective". Journal of Mediterranean knowledge, v. 2, n. 1, pp. 37-58.

https://doi.org/10.26409/2017JMK2.1.03

Gamson, William A.; Croteau, David; Hoynes, William; Sasson, Theodore (1992). "Media images and the social construction of reality". Annual review of sociology, v. 18, n. 1, pp. 373-393.

https://doi.org/10.1146/annurev.so.18.080192.002105

Georgiou, Myria; Zaborowski, Rafal (2017). Council of Europe report. Media coverage of the "refugee crisis": A cross-European perspective. Council of Europe.

https://edoc.coe.int/en/refugees/7367-media-coverage-of-the-refugee-crisis-a-cross-european-perspective.htm/

Gil-Ramírez, Marta; Gómez-de-Travesedo-Rojas, Ruth (2020). “Derechos humanos e inmigración. Repercusión del caso 'Aquarius' en YouTube”. En: Sánchez-Rubio, David; Marín-Conejo, Sergio; Olvera-García, Jorge. Derechos humanos desde la interdisciplinariedad en ciencias sociales y humanidades. Madrid: Dykinson S.L., pp.125- 145. ISBN: 9788413246512 https://bit.ly/37ZXEds

Greenwood, Keith; Thomson, T. J. (2020). "Framing the migration: A study of news photographs showing people fleeing war and persecution". International communication gazette, v. 82, n. 2, pp. 140-163.

https://doi.org/10.1177/1748048519833515

Greussing, Esther; Boomgaarden, Hajo G. (2017). "Shifting the refugee narrative? An automated frame analysis of Europe's 2015 refugee crisis". Journal of ethnic and migration studies, v. 43, n. 11, pp. 1749-1774.

https://doi.org/10.1080/1369183X.2017.1282813

Hangartner, Dominik; Dinas, Elias; Marbach, Moritz; Matakos, Konstantinos; Xefteris, Dimitrios (2019). “Does exposure to the refugee crisis make natives more hostile?". American political science review, v. 113, n. 2, pp. 442-455.

https://doi.org/10.1017/S0003055418000813

Hopkins, Daniel J. (2010). "Politicized places: Explaining where and when immigrants provoke local opposition". The American political science review, v. 104, n. 1, pp. 40-60.

https://doi.org/10.1017/s0003055409990360

Igartua, Juan-José; Muñiz, Carlos (2004). “Encuadres noticiosos e inmigración. Un análisis de contenido de la prensa y televisión españolas”. Zer, v. 16, pp. 87-104.

https://www.ehu.eus/ojs/index.php/zer/article/view/5311

Igartua, Juan-José; Muñiz, Carlos; Otero-Parra, José-Antonio; De-la-Fuente-Juan, Montse (2007). “El tratamiento informativo de la inmigración en los medios de comunicación españoles. Un análisis de contenido desde la teoría del framing". Estudios sobre el mensaje periodístico, v. 13, pp. 91-110.

https://dialnet.unirioja.es/servlet/articulo?codigo $=2558432$

Kaitatzi-Whitlock, Sophia; Kenterelidou, Clio (2017). "The Greek paradigm on the migrant and refugee crisis". In: Barlai, Melani; Fähnrich, Birte; Griessler, Christina; Rhomberg, Markus. The migrant crisis: European perspectives and national discourses. Zürich: LIT, pp. 127-146. ISBN: 9783643908025

Kalkan, Kerem Ozan; Layman, Geoffrey C.; Uslaner, Eric M. (2009). “'Bands of others'? Attitudes toward Muslims in contemporary American society". The journal of politics, v. 71, n. 3, pp. 847-862.

https://doi.org/10.1017/S0003055409990360

Kovár̆, Jan (2019). "A security threat or an economic consequence? An analysis of the news framing of the European Union's refugee crisis". International communication gazette, v. 82, n. 6, pp. 564-587.

https://doi.org/10.1177/1748048519832778 
Kreis, Ramona (2017). “\#refugeesnotwelcome: Anti-refugee discourse on Twitter". Discourse \& communication, v. 11, n. 5, pp. 498-514. https://doi.org/10.1177/1750481317714121

Lenette, Caroline; Cleland, Sienna (2016). "Changing faces: Visual representations of asylum seekers in times of crisis". Creative approaches to research, v. 9. n. 1, pp. 68-83.

https://search.proquest.com/docview/1830031380?pq-origsite=gscholar

López-del-Ramo, Joaquín; Humanes, María-Luisa (2016). “Análisis del framing visual y sus componentes en el tratamiento fotográfico de la crisis de los refugiados sirios en medios de prensa internacional". Scire: representación y organización del conocimiento, v. 22, n. 2, pp. 87-97.

https://ibersid.eu/ojs/index.php/scire/article/view/4395

Maataoui, Mohamed el-Madkouri (2006). "El otro entre nosotros: el musulmán en la prensa”. En: Lario-Bastida, Manuel. Medios de comunicación e inmigración. Murcia: Convivir sin racismo, pp. 97-123. ISBN: 8469021222

http://www.foroellacuria.org/otros/MediosEInmigracion.pdf\#page $=87$

Mandell, Lee M.; Shaw, Donald L. (1973). "Judging people in the news - unconsciously: Effect of camera angle and bodily activity". Journal of broadcasting \& electronic media, v. 17, n. 3, pp. 353-362.

https://doi.org/10.1080/08838157309363698

Marcos-Ramos, María; Igartua, Juan-José; Frutos-Esteban, Francisco-Javier; Barrios-Vicente, Isabel-Matilde; Ortega-Mohedano, Félix; Piñeiro-Naval, Valeriano (2014). "La representación de los personajes inmigrantes en los programas de ficción". Vivat academia, v. 127, pp. 43-72.

https://www.redalyc.org/pdf/5257/525752887003.pdf

Matthes, Jörg (2009). "What's in a frame? A content analysis of media framing studies in the world's leading communication journals, 1990-2005". Journalism \& mass communication quarterly, v. 86, n. 2, pp. 349-367.

https://doi.org/10.1177/107769900908600206

Messaris, Paul; Abraham, Linus (2001). "The role of images in framing news stories". In: Reese, Stephen D.; Gandy, Oscar H.; Grant, August E. Framing public life: Perspectives on media and our understanding of the social world. Mahwah: Lawrence Erlbaum, pp. 215-226. ISBN: 9780805849264

Müller, Karsten; Schwarz, Carlo (2018). Fanning the flames of hate: Social media and hate crime. SSRN.

https://ssrn.com/abstract=3082972

https://doi.org/10.2139/ssrn.3082972

Muñiz, Carlos; Igartua, Juan-José; Otero, José-Antonio (2006). “Imágenes de la inmigración a través de la fotografía de prensa. Un análisis de contenido". Communication \& society, v. 19, n. 1, pp. 103-128.

https://doi.org/10.15581/003.19.1.103-128

Neuendorf, Kimberly A. (2017). The content analysis guidebook. Los Angeles: Sage. ISBN: 9781412979474 https://academic.csuohio.edu/kneuendorf/SkalskiVitae/SkalskiNeuendorfCajigas17.pdf

Nightingale, Alastair; Goodman, Simon; Parker, Sam (2017). "Beyond borders". The psychologist, v. 30, pp. 58-62. https://www.researchgate.net/profile/Alastair_Nightingale/publication/320415315_Beyond_borders/ links/5a9e5292aca272cd09c27599/Beyond-borders.pdf

O’Rourke, Kevin H.; Sinnott, Richard (2006). "The determinants of individual attitudes towards immigration". European journal of political economy, v. 22, n. 4, pp. 838-861.

https://doi.org/10.1016/j.ejpoleco.2005.10.005

Organización para la Seguridad y la Cooperación en Europa (OSCE); Oficina de Instituciones Democráticas y Derechos Humanos (ODIHR) (2019). Hate crime reporting.

https://hatecrime.osce.org

Palacios, Elena (2015). La construcción de los encuadres noticiosos de la inmigración en la prensa de Castilla y León. Tesis doctoral. Salamanca: Universidad de Salamanca.

https://gredos.usal.es/handle/10366/128491

Pantti, Mervi (2016). "Seeing and not seeing the Syrian crisis: New visibility and the visual framing of the Syrian conflict in seven newspapers and their online editions". Jomec journal, v. 4, pp. 1-22.

https://doi.org/10.18573/j.2013.10259

Parrott, Scott; Hoewe, Jennifer; Fan, Minghui; Huffman, Keith (2019). "Portrayals of immigrants and refugees in U.S. news media: Visual framing and its effect on emotions and attitudes". Journal of broadcasting \& electronic media, v. 63, n. 4, pp. 677-697.

https://doi.org/10.1080/08838151.2019.1681860 
Peherson, Samuel; Brown, Rupert; Zagefka, Hanna (2011). "When does national identification lead to the rejection of immigrants? Cross-sectional and longitudinal evidence for the role of essentialist in-group definitions". British journal of social psychology, v. 48, n. 1, pp. 61-76.

https://doi.org/10.1348/014466608X288827

Pew Research Center (2018). Around the world, more say immigrants are a strength than a burden. Spring 2018 global attitudes survey.

https://www.pewresearch.org/global/2019/03/14/around-the-world-more-say-immigrants-are-a-strength-than-a-burden

Piñeiro-Naval, Valeriano; Mangana, Rafael (2019). "La presencia del framing en los artículos publicados en revistas hispanoamericanas de comunicación indexadas en Scopus". Palabra clave, v. 22, n. 1.

https://doi.org/10.5294/pacla.2019.22.1.6

Ramírez-Alvarado, María-del-Mar (2011). “El valor de la fotografía como objeto de estudio y en las investigaciones sobre comunicación: reflexiones teóricas". Discursos fotográficos, v. 7, n. 11, pp. 55-76.

https://doi.org/10.5433/1984-7939.2011v7n11p55

Rodríguez, Lulu; Dimitrova, Daniela V. (2011). "The levels of visual framing". Journal of visual literacy, v. 30, n. 1, pp. 48-65.

https://doi.org/10.1080/23796529.2011.11674684

Said, Edward W. (2011). Cubriendo el Islam: cómo los medios de comunicación y los expertos determinan nuestra visión del resto del mundo. EUA: Debate. ISBN: 9788483066447

Saperas, Enric; Carrasco-Campos, Ángel (2015). "The operationalization of the concept of framing in the Journal of Communication (2009-2013): objects of study, research techniques and theoretical construction". Communication \& society, v. 28, n. 4, pp. 49-66.

https://doi.org/10.15581/003.28.4.49-66

Schemer, Christian (2012). "The Influence of news media on stereotypic attitudes toward immigrants in a political campaign". Journal of communication, v. 62, n. 5, pp. 739-757.

https://doi.org/10.1111/j.1460-2466.2012.01672.x

Seoane-Pérez, Francisco (2017). "Framing of the Syrian refugee crisis in the Spanish press". In: Barlai, Melani; Fähnrich, Birte; Griessler, Christina; Rhomberg, Markus. The migrant crisis: European perspectives and national discourses. Zürich: LIT, pp. 267-282. ISBN: 9783643908025

Stelian, Medianu (2014). The role of the media in the automatic dehumanization of refugees. Doctoral thesis. Electronic thesis and dissertation repository.

https://ir.lib.uwo.ca/etd/2287

Stocchiero, Andrea (2017). "The public debate on the Italian isolation in the European Union migrant crisis". In: Barlai, Melani; Fähnrich, Birte; Griessler, Christina; Rhomberg, Markus. The migrant crisis: European perspectives and national discourses. Zürich: LIT, pp. 169-191. ISBN: 9783643908025

Tajfel, Henri (ed.) (1978). Differentiation between social groups: Studies in the social psychology of intergroup relations. Londres: Academic Press. ISBN: 0126825505

Tajfel, Henri; Turner, John C. (1979). "An intergrative theory of intergroup conflict". In: Austin, William G.; Worchel, Stephen. The social psychology of intergroup relations. Monterey, CA: Brooks/Cole, pp. 33-47. ISBN: 9780818502781

Tirosh, Noam; Klein-Avraham, Inbal (2019). "Memorless. The visual framing of asylum seekers in Israel". Journalism studies, v. 20, n. 3, pp. 381-400.

https://doi.org/10.1080/1461670X.2017.1383857

Tuchman, Gaye (2002). The production of news. In: Bruhn Jensen, Klaus. A handbook of media and communication research: Qualitative and quantitative methodologies. New York: Routledge, pp. 78-90. ISBN: 9780415609661

Valdez-Apolo, María-Belén; Arcila-Calderón, Carlos; Amores, Javier J. (2019). "El discurso del odio hacia migrantes y refugiados a través del tono y los marcos de los mensajes en Twitter". RAEIC, Revista de la Asociación Española de Investigación de la Comunicación, v. 6, n. 12, pp. 361-384.

https://doi.org/10.24137/raeic.6.12.2

Van-Gorp, Baldwin (2005). "Where is the frame? Victims and intruders in the Belgian press coverage of the asylum issue". European journal of communication, v. 20, n. 4, pp. 484-507.

https://doi.org/10.1177/0267323105058253

Verkuyten, Maykel; Mepham, Kieran; Kros, Mathijs (2018). "Public attitudes towards support for migrants: the importance of perceived voluntary and involuntary migration". Ethnic and racial studies, v. 41, n. 5, pp. 901-918.

https://doi.org/10.1080/01419870.2017.1367021 
Vicente-Mariño, Miguel; López-Rabadán, Pablo (2009). “Resultados actuales de la investigación sobre framing: sólido avance internacional y arranque de la especialidad en España”. Zer, v. 14, n. 26, pp. 13-34.

http://repositori.uji.es/xmlui/handle/10234/24502

Vollmer, Bastian; Karakayali, Serhat (2018). "The volatility of the discourse on refugees in Germany". Journal of immigrant \& refugee studies, v. 16, n. 1-2, pp. 118-139.

https://doi.org/10.1080/15562948.2017.1288284

Weaver, David H. (2007). "Thoughts on agenda setting, framing, and priming". Journal of communication, v. 57, n. 1, pp. 142-147.

https://doi.org/10.1111/j.1460-2466.2006.00333.x

Wike, Richard; Stokes, Bruce; Simmons, Katie (2016). "Europeans fear wave of refugees will mean more terrorism, fewer jobs". Pew Research Center, v. 11.

http://www.politico.eu/wp-content/uploads/2016/07/Pew-Research-Center-EU-Refugees-and-National-IdentityReport-EMBARGOED-UNTIL-1800EDT-2200GMT-July-11-2016.pdf

Zhang, Jing (2005). US newspaper coverage of immigration in 2004: A content analysis. Doctoral thesis. Texas A\&M University.

http://oaktrust.library.tamu.edu/bitstream/handle/1969.1/2464/etd-tamu-2005A-STJR-Zhang.pdf

Zhang, Xu; Hellmueller, Lea (2017). "Visual framing of the European refugee crisis in Der Spiegel and CNN International: Global journalism in news photographs". The international communication gazette, v. 79, n. 5, pp. 483-510.

https://doi.org/10.1177/1748048516688134

Zillmann, Dolf; Gibson, Rhonda; Sargent, Stephanie L. (1999). "Effects of photographs in news-magazine reports on issue perception". Media psychology, v. 1, n. 3, pp. 207-228.

https://doi.org/10.1207/s1532785xmep0103_2

\section{Colección de libros de bolsillo El profesional de la información (Editorial UOC) Últimos títulos publicados}
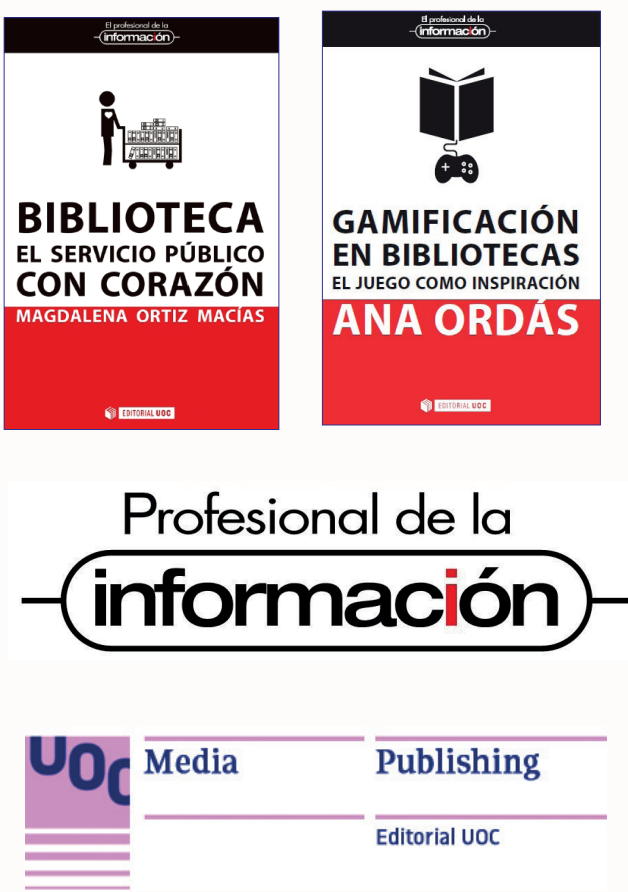

Media

Publishing

Editorial UOC
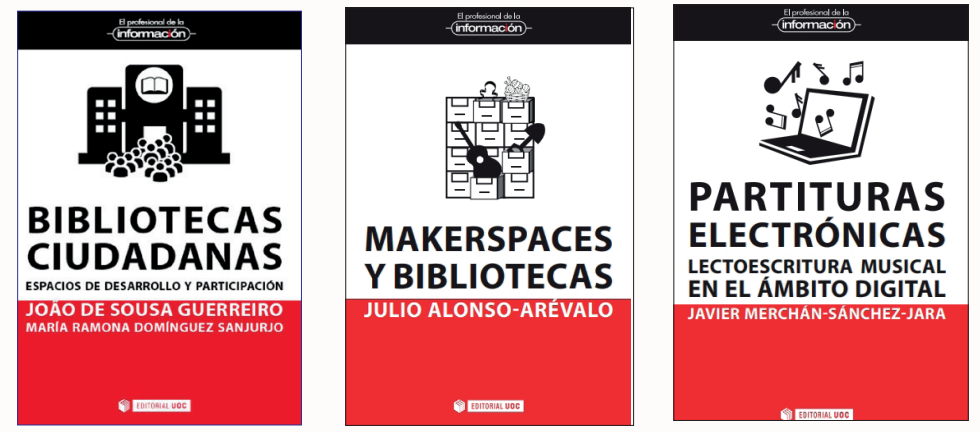

PARTITURAS

ELECTRÓNICAS

LECTOESCRITURA MUSICAL

EN EL AMBITO DIGITAL
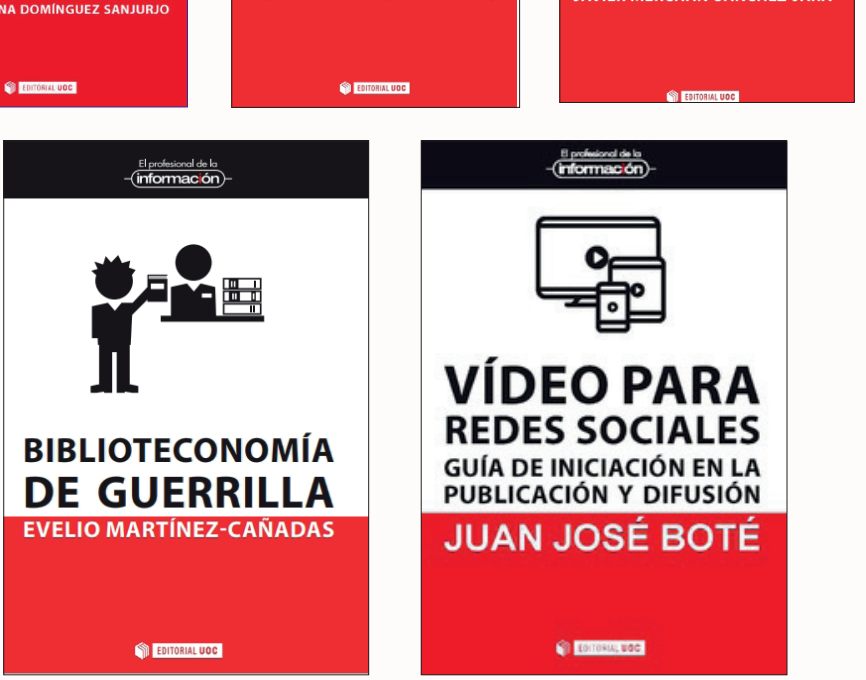

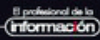

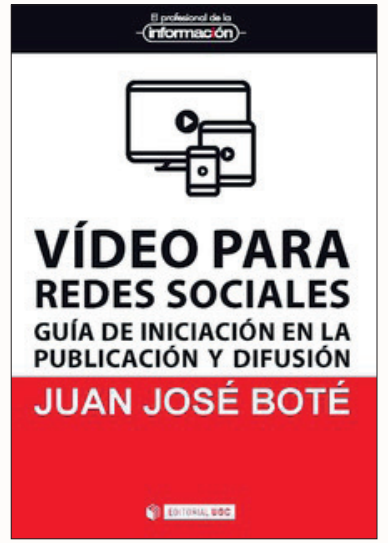

Más información:

http://www.elprofesionaldelainformacion.com/libros.html 